\title{
Quantitative reconstruction of precipitation changes on the NE Tibetan Plateau since the Last Glacial Maximum - extending the concept of pollen source area to pollen-based climate reconstructions from large lakes
}

\author{
Y. Wang ${ }^{1,2}$, U. Herzschuh ${ }^{1,2}$, L. S. Shumilovskikh ${ }^{3}$, S. Mischke ${ }^{2,4}$, H. J. B. Birks ${ }^{5,6,7,8}$, J. Wischnewski ${ }^{1,2}$, J. Böhner ${ }^{9}$, \\ F. Schlütz ${ }^{3,10}$, F. Lehmkuhl ${ }^{11}$, B. Diekmann ${ }^{1}$, B. Wünnemann ${ }^{12}$, and C. Zhang ${ }^{13}$ \\ ${ }^{1}$ Alfred Wegener Institute for Polar and Marine Research, Research Unit Potsdam, Telegrafenberg A43, \\ 14473 Potsdam, Germany \\ ${ }^{2}$ Institute of Earth and Environmental Science, University of Potsdam, Karl-Liebknecht-Str. 24, 14476 Potsdam, Germany \\ ${ }^{3}$ Department of Palynology and Climate Dynamics, Albrecht-von-Haller Institute for Plant Sciences, University of Göttingen, \\ Untere Karspüle 2, 37073 Göttingen, Germany \\ ${ }^{4}$ Institute of Geological Sciences, Free University Berlin, Malteserstr. 74-100, 12249 Berlin, Germany \\ ${ }^{5}$ Department of Biology, University of Bergen, Thormøhlensgate 53A, 5006 Bergen, Norway \\ ${ }^{6}$ Bjerknes Centre for Climate Research, Allegaten 55, 5007 Bergen, Norway \\ ${ }^{7}$ Environmental Change Research Centre, University College London, London, WC1E 6BT, UK \\ ${ }^{8}$ School of Geography and the Environment, University of Oxford, Oxford, OX1 3QY, UK \\ ${ }^{9}$ Institute for Geography, University Hamburg, Bundesstr. 55, 20145 Hamburg, Germany \\ ${ }^{10}$ Institute of Geographical Sciences, Free University Berlin, Malteserstr. 74-100, 12249 Berlin, Germany \\ ${ }^{11}$ Department of Geography, RWTH Aachen University, Templergraben 55, 52056 Aachen, Germany \\ ${ }^{12}$ School of Geography and Oceanography, Nanjing University, Hankou Road 22, 210093 Nanjing, China \\ ${ }^{13}$ Centre for Arid Environment and Paleoclimate Research, School of Resources and Environmental Sciences, \\ Lanzhou University, 730000 Lanzhou, China
}

Correspondence to: Y. Wang (yongbowang@gmail.com)

Received: 10 June 2013 - Published in Clim. Past Discuss.: 28 June 2013

Revised: 6 November 2013 - Accepted: 7 November 2013 - Published: 8 January 2014

\begin{abstract}
Pollen records from large lakes have been used for quantitative palaeoclimate reconstruction, but the influences that lake size (as a result of species-specific variations in pollen dispersal patterns that smaller pollen grains are more easily transported to lake centre) and taphonomy have on these climatic signals have not previously been systematically investigated. We introduce the concept of pollen source area to pollen-based climate calibration using the north-eastern Tibetan Plateau as our study area. We present a pollen data set collected from large lakes in the arid to semiarid region of central Asia. The influences that lake size and the inferred pollen source areas have on pollen compositions have been investigated through comparisons with pollen assemblages in neighbouring lakes of various sizes. Modern
\end{abstract}

pollen samples collected from different parts of Lake Donggi Cona (in the north-eastern part of the Tibetan Plateau) reveal variations in pollen assemblages within this large lake, which are interpreted in terms of the species-specific dispersal and depositional patterns for different types of pollen, and in terms of fluvial input components. We have estimated the pollen source area for each lake individually and used this information to infer modern climate data with which to then develop a modern calibration data set, using both the multivariate regression tree (MRT) and weighted-averaging partial least squares (WA-PLS) approaches. Fossil pollen data from Lake Donggi Cona have been used to reconstruct the climate history of the north-eastern part of the Tibetan Plateau since the Last Glacial Maximum (LGM). The mean 
annual precipitation was quantitatively reconstructed using WA-PLS: extremely dry conditions are found to have dominated the LGM, with annual precipitation of around $100 \mathrm{~mm}$, which is only $32 \%$ of present-day precipitation. A gradually increasing trend in moisture conditions during the Late Glacial is terminated by an abrupt reversion to a dry phase that lasts for about $1000 \mathrm{yr}$ and coincides with "Heinrich event 1" in the North Atlantic region. Subsequent periods corresponding to the Bølling/Allerød interstadial, with annual precipitation $\left(P_{\mathrm{ann}}\right)$ of about $350 \mathrm{~mm}$, and the Younger Dryas event (about $270 \mathrm{~mm} P_{\text {ann }}$ ) are followed by moist conditions in the early Holocene, with annual precipitation of up to $400 \mathrm{~mm}$. A drier trend after $9 \mathrm{cal}$. ka BP is followed by a second wet phase in the middle Holocene, lasting until $4.5 \mathrm{cal}$. ka BP. Relatively steady conditions with only slight fluctuations then dominate the late Holocene, resulting in the present climatic conditions. The climate changes since the LGM have been primarily driven by deglaciation and fluctuations in the intensity of the Asian summer monsoon that resulted from changes in the Northern Hemisphere summer solar insolation, as well as from changes in the North Atlantic climate through variations in the circulation patterns and intensity of the westerlies.

\section{Introduction}

The study of past natural climate change and its underlying driving mechanisms, especially during the Late Glacial and the Holocene, provides an indispensable key to predicting future climatic conditions. Due to its global significance for atmospheric circulation and climate change, the Tibetan Plateau has become a focus for several palaeoclimatological studies in recent years, and over the last two decades a variety of records have been recovered from lake sediments (e.g. Gasse et al., 1991; Shen et al., 2005), ice cores (Thompson et al., 1997; Liu et al., 1998), and peat sections (Hong et al., 2005). It has been assumed that changes in the monsoonderived moisture supply generally followed variations in the Northern Hemisphere summer insolation (An et al., 2000; Herzschuh, 2006; Wang et al., 2010). However, discrepancies exist not only between records from different climatic regions but also between records from the same region, owing to the very large size of the plateau, the complex geographic settings within the plateau, and the regional variations in the relative importance of specific circulation systems such as the east Asian summer monsoon (EASM), the Indian summer monsoon, and the westerlies. For instance, the effective moisture changes during the Holocene show various patterns over the Tibetan Plateau according to the cluster analysis in Wischnewski et al. (2011). Even individual proxies from the same site may indicate discrepancies in moisture evolution as they can reflect either local within-lake variations (diatom), or regional variations (pollen) (Wischnewski et al., 2011).
Pollen analyses from lacustrine sediments have been widely used to provide an indication of changes in palaeovegetation and/or palaeoclimate (Birks, 1981; Yu et al., 1998; Birks and Seppä, 2004; Zhao et al., 2009a; Birks et al., 2010; Xu et al., 2010a). Modern pollen-climate calibration sets have recently been developed and applied to the Tibetan Plateau (Shen et al., 2006; Herzschuh et al., 2010; Lu et al., 2011). The pollen records of lake sediments reflect signals within the pollen source area - the area from which all (or most) of the pollen grains in lakes are derived (Prentice, 1985; Sugita, 1993, 1994; Borström et al., 2008). The inferred size of this source area, however, can vary with the size of the lake basin as well as the species-specific pollen dispersal and depositional characteristics (Tauber, 1965, 1977; Janssen, 1966, 1973; Anderson, 1970; Jacobson and Bradshaw, 1981; Parsons and Prentice, 1981; Prentice, 1985; Schwartz, 1989). Most of these early studies have focused on estimating pollen deposition at a point in the centre of a sedimentary basin, which is not appropriate for lake sediments as the pollen deposition in lakes could be further mixed in the water column, for example. A theoretical model to estimate the pollen source area for an entire lake surface was then developed by Sugita (1993), in which the size of the $50 \%$ pollen source area was calculated, but its implications have rarely been taken into account in pollen-based climate calibration studies. It might, for example, be problematic to apply pollen-climate calibration functions that are based on samples of surface soil or surface sediments from small lakes, to larger lakes (Birks, 2003; Zhao et al., 2009b; Birks et al., 2010; Goring et al., 2010; Xu et al., 2010b). Furthermore, there can clearly be large variations in pollen spectra within individual large lakes, mostly due to differences in grain size, settling velocity, and related dispersal patterns in the atmosphere (Davis, 1963, 1967; Sun and Wu, 1987; Luly, 1997; Huang et al., 2004; Giesecke and Fontana, 2008). In addition, within-lake hydrodynamics and/or fluvial input of pollen from the hydrological catchment can lead to further selective deposition within individual lakes (Debusk, 1997; Zhu et al., 2002; Xu et al., 2005).

Our objectives in this study were twofold. First, we examined the influences that pollen source area and withinlake pollen variations have had on palaeoclimate reconstructions. For this purpose we compiled a pollen-climate calibration data set based solely on modern pollen spectra from large lakes in arid and semi-arid central Asian areas, together with a set of surface sediment samples from Lake Donggi Cona, a large lake in the north-eastern part of the Tibetan Plateau. We applied these findings to quantitative interpretations of climate and vegetation from the Lake Donggi Cona fossil pollen record, covering the time interval from the LGM to the Holocene. We then compared the pollen-based results with ostracod data from the same core using numerical methods, and also with other pollen records from nearby lakes in order to validate our climate reconstructions. Second, we compared the resulting climatic reconstruction from 
Lake Donggi Cona to other quantitative records from the Tibetan Plateau, in order to determine both the strength of the inferred changes in climate and the drivers behind these changes.

\section{Study area}

Lake Donggi Cona $\left(35.22-35.83^{\circ} \mathrm{N}, \quad 98.33-98.75^{\circ} \mathrm{E}\right.$; $4090 \mathrm{~m}$ a.s.l.), covering an area of about $230 \mathrm{~km}^{2}$, is located on the north-eastern Tibetan Plateau, to the north-west and east of the Anemaqin and Kunlun mountain ranges, respectively (Wang and Dou, 1998; Dietze et al., 2010). The catchment area of the lake is $3174 \mathrm{~km}^{2}$ and encompasses the foothills of the Anemaqin mountain range to the south-east with highest peaks of around $5200 \mathrm{~m}$, and a slightly lower mountain range to the north. The lake is fed from the east by a perennial river, the Dong $\mathrm{Qu}$, and some episodic inflows from the north that form three major pro-grading arcuate delta systems (Dietze et al., 2010). The outflow from the lake is controlled by a gauge station set up during the 1970s and feeds into the Tuosu River, which flows into the Qaidam River and thence into the endorheic Qaidam Basin to the north-west (Fig. 1b) (Wang and Dou, 1998; Dietze et al., 2010). For further details on the catchment characteristics, basin morphology, and limnology of Lake Donggi Cona, see Mischke et al. (2010a, b) and Dietze et al. (2010).

The climate in this region, which is dominated by both the monsoon system and the extra-tropical westerlies, shows strong seasonal contrasts in precipitation and temperature. The mean annual temperature is $-3.0^{\circ} \mathrm{C}$, with mean January and July temperatures of $-15.9^{\circ} \mathrm{C}$ and $7.8^{\circ} \mathrm{C}$, and maximum January and July temperatures of $-7.6^{\circ} \mathrm{C}$ and $13.6^{\circ} \mathrm{C}$, respectively. The mean annual precipitation is $311 \mathrm{~mm}$, of which $76 \%$ falls during the monsoon season (June, July, August, and September) (Fig. 1c). Cold, dry air and northerly winds prevail during the winter season as a result of the Asian winter monsoon, reflecting the influence of the SiberianMongolian High. Meteorological data since 1953 are available from the nearest climate station at Madoi, $50 \mathrm{~km}$ to the south-west of Lake Donggi Cona (WorldClimate: http: //www.worldclimate.com).

The areas in the immediate vicinity of the lake have an alpine steppe vegetation dominated by Kobresia (Cyperaceae), Artemisia, and Poaceae, while the relatively moist Anemaqin mountain range supports alpine meadows (Kobresia spp.) and patches of alpine shrubs (Salix) with Saussurea spp. and Potentilla spp. (Kürschner et al., 2005; Wang et al., 2006).

\section{Materials and methods}

\subsection{Surface sediment sample collection, pollen source area estimation, and climate data}

The modern pollen data set consists of 53 surface sediment samples from large lakes (with shortest radii greater than $750 \mathrm{~m}$ ), in which 29 samples were collected and identified by our research team, with information on the remainder derived from published literature or personal communications (see details in Table 1). The 29 surface sediment samples from large lakes, together with 9 samples from small lakes (with shortest radii less than $200 \mathrm{~m}$ ) situated close to a large lake, were collected from the Tibetan Plateau and the arid western China area (together with two sites from Tajikistan) during field expeditions between 2002 and 2011 (Fig. 1a, Table 1, and Table S1 in the Supplement). Surface sediment samples were collected with a sediment grab or gravity corer from depths of $0-2 \mathrm{~cm}$ in the centre of each lake which, according to unpublished $\left({ }^{137} \mathrm{Cs},{ }^{210} \mathrm{~Pb}\right)$ radiometric dating results, represent deposition during the last 20-30 yr. In order to extend the climate gradient of our modern data set, we also included a few sites from the Qaidam Basin and the Xinjiang lowlands, which may provide an analogue for the temperate steppe vegetation on the Tibetan Plateau during the early Holocene.

The pollen source area for each large lake was estimated following Sugita's (1993) model for lake basins, which has the following inherent assumptions: (1) the sampling basin is a circular opening in the vegetation canopy, with the circular approximation of the basin shape for irregularly shaped lakes being based on the shortest radius (Bunting and Middleton, 2005); (2) winds are uniform from all directions; and (3) the dominant components of pollen transport are wind above the canopy and gravity below the canopy. Although many of our sampled lakes have inflows from rivers, we believe that wind remains the dominant driver for pollen transportation since (a) our lakes are located within flat plains rather than in mountainous regions, which is ideal topography for aeolian transportation; (b) although the fluvial inflows derive mainly from higher-elevation glaciers and the vegetation within their catchment areas is consistent with the vegetation components in the pollen source area, the total coverage of these upper catchments is much smaller and they will therefore not have contributed much pollen loading to the lakes; and (c) the inflows in such arid and semi-arid regions are not very large and are insufficient to transport large quantities of pollen grains into the lakes. Thus the pollen source areas, the areas from which $50 \%$ of the pollen grains are derived (here we use $50 \%$ according to the calculation in Sugita, 1993), for four major pollen species (Artemisia, Chenopodiaceae, Poaceae, and Cyperaceae) have been estimated using the lake radii (see details in Table 1), a wind speed of $3 \mathrm{~m} \mathrm{~s}^{-1}$ (which is commonly used for pollen-vegetation modelling studies; e.g. Sugita, 1993), and the pollen-fall speeds (Table 2) as 
Table 1. Location, lake size, calculated pollen source area and corresponding climate data from large lakes.

\begin{tabular}{|c|c|c|c|c|c|c|c|c|c|}
\hline No. & $\begin{array}{l}\text { Lake } \\
\text { name }\end{array}$ & $\begin{array}{r}\text { Latitude } \\
\left({ }^{\circ} \mathrm{N}\right)\end{array}$ & $\begin{array}{r}\text { Longitude } \\
\left({ }^{\circ} \mathrm{E}\right)\end{array}$ & $\begin{array}{r}\text { Elevation } \\
\text { (ma.s.l.) }\end{array}$ & $\begin{array}{r}R_{\text {Lake }} \\
(\mathrm{m})\end{array}$ & $\begin{array}{r}R_{\mathrm{PSA}} \\
(\mathrm{km})\end{array}$ & $\begin{array}{r}P_{\mathrm{ann}}^{*} \\
(\mathrm{~mm})\end{array}$ & $\begin{array}{l}T_{\text {July }}^{*} \\
\left({ }^{\circ} \mathrm{C}\right)\end{array}$ & $\begin{array}{l}\text { Pollen data } \\
\text { source }\end{array}$ \\
\hline LS-1 & Wulungu Lake & 47.07 & 87.26 & 475 & 15000 & 250 & 106.5 & 23.4 & this study \\
\hline LS-2 & Manas Lake & 45.75 & 85.71 & 235 & 4000 & 160 & 72.0 & 26.4 & this study \\
\hline LS-3 & Aibi Lake & 45.07 & 82.81 & 181 & 12000 & 240 & 157.9 & 23.8 & this study \\
\hline LS-4 & Salimu Lake & 44.58 & 81.20 & 2074 & 10000 & 210 & 485.3 & 13.7 & Jiang et al. (2013) \\
\hline LS-5 & Balikun Lake & 43.63 & 92.79 & 1574 & 6800 & 140 & 129.5 & 20.1 & this study \\
\hline LS-6 & Tuoniekunie Lake & 43.41 & 94.15 & 1890 & 1250 & 90 & 94.2 & 17.4 & this study \\
\hline LS-7 & Boston & 41.90 & 86.71 & 1048 & 10000 & 170 & 54.6 & 24.4 & Demeske (unpublished) \\
\hline LS-8 & DaQaidam Lake & 39.06 & 94.18 & 2821 & 1900 & 50 & 60.8 & 15.4 & Zhao et al. (2009b) \\
\hline LS-9 & Karakuli (Taj) Lake & 39.02 & 73.51 & 3926 & 7500 & 180 & 431.3 & 5.9 & this study \\
\hline LS-10 & Sugan Lake & 38.80 & 93.70 & 2772 & 3500 & 90 & 55.1 & 13.5 & Zhao et al. (2009b) \\
\hline LS-11 & Karakuli Lake & 38.44 & 75.06 & 3657 & 1250 & 90 & 262.6 & 10.1 & this study \\
\hline LS-12 & Gasikule & 38.05 & 90.70 & 2853 & 4500 & 90 & 118.7 & 15.5 & Zhao et al. (2009b) \\
\hline LS-13 & Tuskul Lake & 37.68 & 73.18 & 3678 & 1250 & 40 & 424.1 & 8.6 & this study \\
\hline LS-14 & Hurleg Lake & 37.18 & 96.55 & 2850 & 4000 & 60 & 62.9 & 15.9 & Zhao et al. (2009b) \\
\hline LS-15 & Toson Lake & 37.08 & 97.00 & 2813 & 7500 & 110 & 98.6 & 16.7 & Zhao et al. (2009b) \\
\hline LS-16 & Gahai & 37.08 & 97.31 & 2848 & 2500 & 100 & 123.7 & 16.0 & Zhao et al. (2009b) \\
\hline LS-17 & unknown & 36.87 & 101.03 & 2965 & 750 & 20 & 478.4 & 10.7 & Herzschuh et al. (2010) \\
\hline LS-18 & Haiyan & 36.81 & 100.57 & 3194 & 4500 & 140 & 449.3 & 10.6 & Zhao et al. (2009b) \\
\hline LS-19 & Qinghai Lake & 36.61 & 100.57 & 3196 & 17500 & 240 & 483.4 & 10.8 & Zhao et al. (2009b) \\
\hline LS-20 & Erhai & 36.56 & 100.74 & 3189 & 750 & 60 & 467.9 & 10.8 & Zhao et al. (2009b) \\
\hline LS-21 & Chaka & 36.46 & 99.05 & 3121 & 4500 & 100 & 510.5 & 9.5 & Zhao et al. (2009b) \\
\hline LS-22 & Heihai & 35.97 & 93.29 & 4437 & 2500 & 80 & 167.5 & 6.6 & this study \\
\hline LS-23 & Kusai Lake & 35.65 & 92.98 & 4487 & 5500 & 90 & 198.8 & 6.3 & this study \\
\hline LS-24 & Haiding Nur & 35.61 & 93.18 & 4468 & 1700 & 40 & 180.1 & 6.5 & this study \\
\hline LS-25 & Kuhai & 35.31 & 99.18 & 4150 & 3100 & 70 & 459.6 & 7.8 & Herzschuh et al. (2010) \\
\hline LS-26 & Donggi Cona & 35.28 & 98.64 & 4095 & 7500 & 90 & 375.2 & 8.4 & Herzschuh et al. (2010) \\
\hline LS-27 & unknown & 35.04 & 97.90 & 4260 & 1150 & 70 & 349.6 & 7.8 & Herzschuh et al. (2010) \\
\hline LS-28 & unknown & 35.02 & 97.63 & 4284 & 12000 & 80 & 324.8 & 7.7 & Herzschuh et al. (2010) \\
\hline LS-29 & unknown & 34.97 & 97.61 & 4285 & 750 & 10 & 331.3 & 7.8 & Herzschuh et al. (2010) \\
\hline LS-30 & E Ling $\mathrm{Hu}$ & 34.93 & 97.27 & 4303 & 10000 & 90 & 320.3 & 7.6 & Herzschuh et al. (2010) \\
\hline LS-31 & Ulanul Lake & 34.87 & 90.50 & 4854 & 3500 & 60 & 310.9 & 5.8 & Shan et al. (1996); Ni et al. (2010) \\
\hline LS-32 & unknown & 34.86 & 98.10 & 4227 & 1900 & 40 & 378.1 & 7.8 & Herzschuh et al. (2010) \\
\hline LS-33 & Xingxinghai & 34.83 & 98.01 & 4218 & 1500 & 20 & 389.4 & 7.9 & this study \\
\hline LS-34 & Zhongxing Hai & 34.80 & 98.21 & 4230 & 2400 & 50 & 388.8 & 7.9 & Herzschuh et al. (2010) \\
\hline LS-35 & Geren Co & 34.59 & 92.45 & 4650 & 1250 & 100 & 285.5 & 5.8 & $\begin{array}{l}\text { Yu et al. (2001); Ni et al. (2010); } \\
\text { Chen et al. (2011) }\end{array}$ \\
\hline LS-36 & Gahai & 34.24 & 102.33 & 3485 & 2800 & 40 & 720.8 & 9.8 & Herzschuh et al. (2010) \\
\hline LS-37 & Bangong Co & 33.44 & 79.12 & 4300 & 1250 & 70 & 308.2 & 8.0 & van Campo et al. (1996) \\
\hline LS-38 & Ximen Co & 33.38 & 101.47 & 4020 & 750 & 10 & 866.0 & 8.5 & Herzschuh (unpublished) \\
\hline LS-39 & Cuolongda & 33.35 & 96.01 & 4590 & 1500 & 50 & 613.6 & 5.4 & this study \\
\hline LS-40 & NianjieCuo & 33.01 & 96.35 & 4586 & 1500 & 40 & 569.9 & 6.6 & this study \\
\hline LS-41 & unknown & 32.15 & 91.44 & 4616 & 750 & 5 & 550.2 & 8.6 & Herzschuh et al. (2010) \\
\hline LS-42 & Cuona & 32.07 & 91.40 & 4740 & 4500 & 40 & 502.9 & 8.8 & $\begin{array}{l}\text { Yu et al. (2001); Ni et al. (2010); } \\
\text { Chen et al. (2011) }\end{array}$ \\
\hline LS-43 & unknown & 32.03 & 90.51 & 4681 & 750 & 20 & 485.4 & 8.6 & Herzschuh et al. (2010) \\
\hline LS-44 & Xuguo Co & 31.97 & 90.33 & 4540 & 3500 & 40 & 443.2 & 9.1 & $\begin{array}{l}\text { Yu et al. (2001); Ni et al. (2010); } \\
\text { Chen et al. (2011) }\end{array}$ \\
\hline LS-45 & Dasta Co & 31.83 & 87.56 & 4478 & 8000 & 80 & 352.0 & 10.9 & Herzschuh et al. (2010) \\
\hline LS-46 & Selin Co & 31.57 & 88.52 & 4530 & 12500 & 50 & 490.0 & 9.1 & Sun et al. (1993) \\
\hline LS-47 & Peng Co & 31.52 & 91.03 & 4522 & 3500 & 20 & 453.2 & 9.3 & $\begin{array}{l}\text { Yu et al. (2001); Ni et al. (2010); } \\
\text { Chen et al. (2011) }\end{array}$ \\
\hline LS-48 & unknown & 31.50 & 90.02 & 4685 & 750 & 20 & 460.7 & 8.5 & Herzschuh et al. (2010) \\
\hline LS-49 & Co Ngion & 31.47 & 91.50 & 4515 & 3000 & 60 & 522.7 & 8.8 & $\begin{array}{l}\text { Yu et al. (2001); Ni et al. (2010); } \\
\text { Chen et al. (2011) }\end{array}$ \\
\hline LS-50 & unknown & 31.47 & 90.04 & 4673 & 750 & 10 & 430.5 & 8.7 & Herzschuh et al. (2010) \\
\hline LS-51 & Nariping Co & 31.29 & 91.47 & 4520 & 3500 & 30 & 501.3 & 8.8 & $\begin{array}{l}\text { Yu et al. (2001); Ni et al. (2010); } \\
\text { Chen et al. (2011) }\end{array}$ \\
\hline LS-52 & Nam Co & 30.71 & 90.87 & 4710 & 12500 & 140 & 648.5 & 7.4 & $\begin{array}{l}\text { Yu et al. (2001); Ni et al. (2010); } \\
\text { Chen et al. (2011) }\end{array}$ \\
\hline LS-53 & Cengco & 28.97 & 90.52 & 4421 & 1900 & 70 & 544.0 & 9.3 & $\begin{array}{l}\text { Yu et al. (2001); Ni et al. (2010); } \\
\text { Chen et al. (2011) }\end{array}$ \\
\hline
\end{tabular}

$R_{\text {Lake }}$, lake radius; $R_{\mathrm{PAS}}$, radius of estimated pollen source area; $P_{\mathrm{ann}}^{*}, T_{\mathrm{July}}^{*}$, inverse-distance-weighted precipitation and temperature data within the pollen source area. 


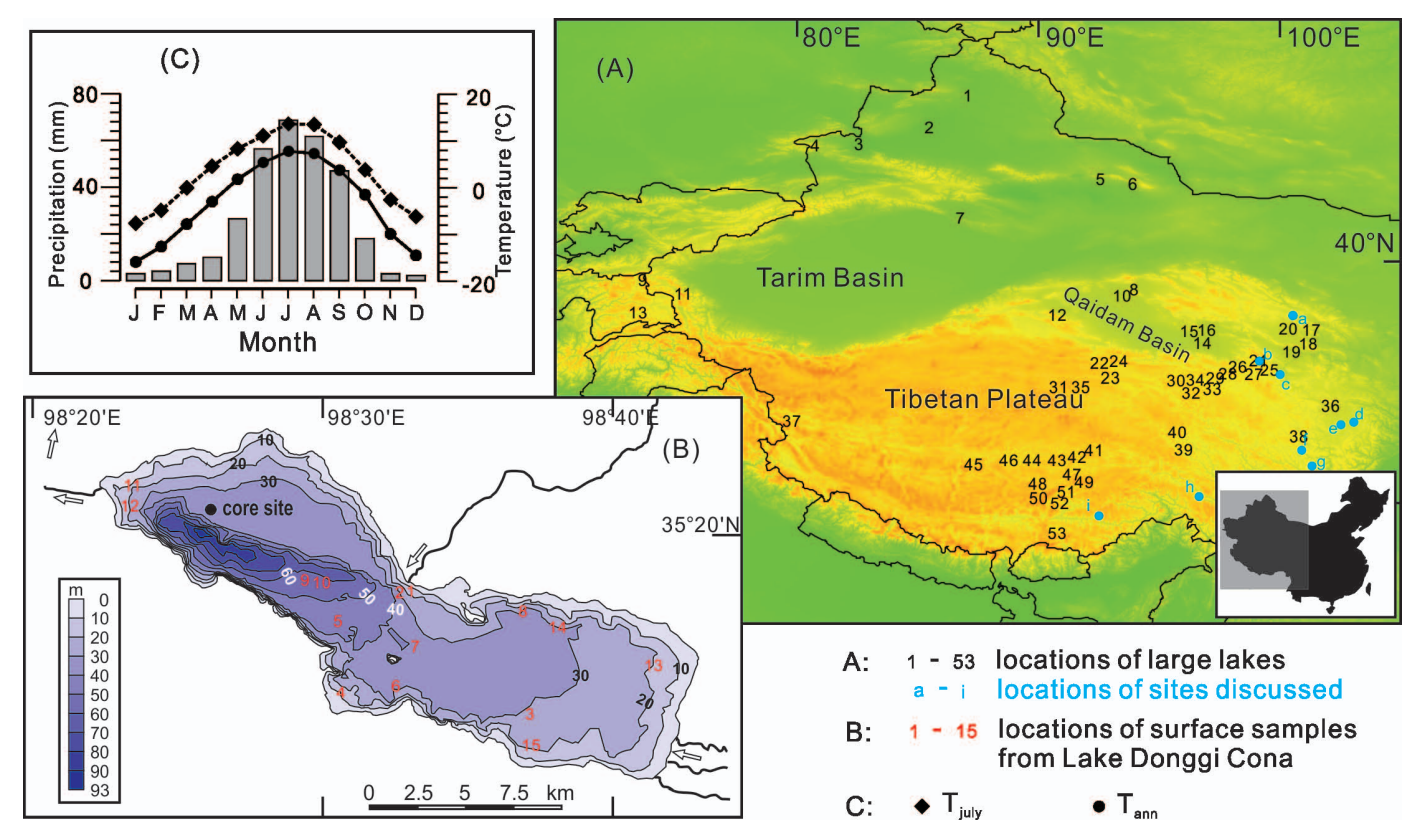

Fig. 1. (A) Overview of the study area and the locations of the large lakes sampled (1-53, see detailed information in Table 1), as well as study sites mentioned in the text: a, Lake Luanhaizi; b, Lake Donggi Cona; c, Kuhai Lake; d, no. 2 pit; e, Lake Ximen Co; f, Naleng Lake; g, Yidun Lake; h, Ren Co; i, Hidden Lake. (B) Bathymetric map of Lake Donggi Cona showing the surface sediment sample locations (1-15) and the core site (PG1790), with arrows indicating the major inflows and outflows. (C) Meteorological data between 1950 and 1990 AD, from the Madoi station: mean annual precipitation $\left(P_{\mathrm{ann}}\right.$, bars), mean annual temperature $\left(T_{\mathrm{ann}}\right.$, points) and mean July temperature $\left(T_{\mathrm{July}}\right.$, diamonds).

model parameters. The pollen source area for each lake was then derived from the pollen source areas of each species, using their proportions within the total pollen assemblage (see Eq. 1 below), and the size of the pollen source area was expressed as its radius $R_{\mathrm{PSA}}$, representing the distance from the sampled lake.

$$
\begin{gathered}
\mathrm{PSA}_{\text {lake }}=\mathrm{PSA}_{1} \times \mathrm{Per}_{1}+\mathrm{PSA}_{2} \times \mathrm{Per}_{2} \\
+\mathrm{PSA}_{3} \times \mathrm{Per}_{3}+\mathrm{PSA}_{4} \times \mathrm{Per}_{4}
\end{gathered}
$$

$\mathrm{PSA}_{\text {lake }}$ stands for the pollen source area of the lake, PSA (14) indicate the size of the pollen source area for each taxon, and Per (1-4) are the pollen proportions for each taxon.

Site-specific climate information on mean annual precipitation and mean July temperature was obtained from Böhner (2006). Climate estimates (precipitation, temperature, radiation, evapotranspiration) with a monthly resolution were derived on a regular grid network $(3500 \times 4000$ grid cells $)$ covering the central and high Asian regions, with a grid-cell spacing of $1 \mathrm{~km}^{2}$ (Böhner, 2006). The statistical downscaling approach at the core of this geospatial climate modelling integrates gridded circulation variables (GCM data, re-analysis series), available station observations (climate records from more than 400 climate stations), and advanced terrain parameterisation methods (Böhner and Antonic, 2008; Soria-Auza et al., 2010) to account for the topoclimatic heterogeneity of central Asia. A detailed description of the methods used is given in Böhner (2005). Considering the fact that the vegeta- tion close to the lake should have higher contribution to the pollen assemblage in the lake sediments, an inverse-distanceweighting (IDW) method was applied to estimate the climatic factors for each lake according to the data within its pollen source area.

\subsection{Coring, surface sediment sampling of Lake Donggi Cona, and radiocarbon dating}

A $4.84 \mathrm{~m}$-long sediment core (PG1790) was recovered from $98.436^{\circ} \mathrm{E}, 35.345^{\circ} \mathrm{N}$ using a UWITEC "Niederreiter $60^{\circ}$ piston corer, under a water depth of $34.7 \mathrm{~m}$ (Fig. 1a). Xray fluorescence data were used to correlate and calibrate the overlaps between the four core segments. The sediments consist mainly of carbonate-rich laminated lake mud. Light and dark laminae a few millimetres thick occur in the lower and upper sections of the core, while one-millimetre-thick couplets dominate between 2.3 and $3.6 \mathrm{~m}$ core depth. Sediments in the upper $1 \mathrm{~m}$ of the core have a mottled appearance, probably as a result of bioturbation by benthic invertebrates. In addition to the sediment core, 15 surface sediment samples (0-2 cm depth) were collected from different parts of Lake Donggi Cona using a sediment grab (Fig. 1c).

Because of the absence of macrofossils, total organic carbon (TOC) was used for accelerator mass spectrometry (AMS) ${ }^{14} \mathrm{C}$ dating, carried out at the Poznan Radiocarbon Laboratory in Poland. As previously reported from the 
Table 2. Results of pollen grain size measurements and calculated fall speeds for four major pollen taxa.

\begin{tabular}{|c|c|c|c|c|c|}
\hline \multirow{2}{*}{$\begin{array}{l}\text { Pollen } \\
\text { species }\end{array}$} & \multirow{2}{*}{$\begin{array}{r}\text { Measured } \\
\text { grains }\end{array}$} & \multicolumn{3}{|c|}{ Radius of pollen grain $(\mu \mathrm{m})$} & \multirow{2}{*}{$\begin{array}{r}\begin{array}{r}\text { Pollen } \\
\text { fall speed }\end{array} \\
\left(\mathrm{m} \mathrm{s}^{-1}\right)\end{array}$} \\
\hline & & Max. & Min. & Mean & \\
\hline Artemisia & 30 & 11.67 & 6.67 & 9.11 & 0.0101 \\
\hline Chenopodiaceae & 30 & 13.33 & 6.67 & 9.75 & 0.0117 \\
\hline Poaceae & 30 & 20.00 & 9.17 & 12.31 & 0.0185 \\
\hline Cyperaceae & 30 & $\begin{array}{l}25.00^{\mathrm{a}} \\
18.33^{\mathrm{b}}\end{array}$ & $\begin{array}{l}15.00^{\mathrm{a}} \\
11.67^{\mathrm{b}}\end{array}$ & $\begin{array}{l}17.69^{\mathrm{a}} \\
15.03^{\mathrm{b}}\end{array}$ & 0.0291 \\
\hline
\end{tabular}

${ }^{\mathrm{a}}$ long axis; ${ }^{\mathrm{b}}$ short axis; ${ }^{\mathrm{c}}$ according to Stoke's law (Gregory, 1973).

Tibetan Plateau area, the ${ }^{14} \mathrm{C}$ ages are commonly affected by the "hard water effect" (Morrill et al., 2006; Liu et al., 2009; Henderson et al., 2010). Sediments from the top $1 \mathrm{~cm}$ of the core were used for radiocarbon-dating to estimate this effect, which yields an offset of about $2000 \mathrm{yr}$. In total, 17 ${ }^{14} \mathrm{C}$ ages from 13 depth layers were processed, corrected, and calibrated using the OxCal 4.1 program and the IntCal09 calibration data (Bronk Ramsey, 2009; Reimer et al., 2009). OxCal 4.1 was also used to establish an age-depth relationship using a Bayesian approach, which integrates the radiocarbon dates with their stratigraphical positions and lithological changes to develop the most plausible age-depth model, given the available data (for a detailed description see Mischke et al., 2010b).

\subsection{Pollen sample treatment and analysis}

Fossil pollen samples were taken at $4 \mathrm{~cm}$ intervals for the Holocene period and $8 \mathrm{~cm}$ intervals for the older stages. In total, 53 surface sediment and 77 fossil pollen samples were treated and analysed following standard laboratory methods, including treatment with hydrogen chloride $(\mathrm{HCl}, 10 \%)$, potassium hydroxide $(\mathrm{KOH}, 10 \%)$, and hydrofluoric acid (HF, 50\%), as well as acetolysis, fine sieving (with a $7 \mu \mathrm{m}$ mesh in an ultrasonic bath), and mounting in glycerine (Fægri and Iversen, 1989). Two tablets of Lycopodium spores were added to the fossil samples for estimation of absolute pollen concentrations. The identification of pollen types was based on relevant published literature (Moore et al., 1991; Wang et al., 1997; Beug, 2004) and type collections. A minimum of 300 terrestrial pollen grains were counted, apart from 23 samples from the Lake Donggi Cona core that were older than $13.5 \mathrm{cal}$. ka BP and had very low pollen concentrations (200-2000 grains $\mathrm{cm}^{-3}$ ). For these 23 samples, only 50-150 pollen grains were counted since the local vegetation coverage and diversity were far lower than during either the Holocene period or the present, and the rare species only have minor influences on the climate reconstructions (Herzschuh et al., 2009; Wischnewski et al., 2011).

\subsection{Numerical analyses}

Pollen percentages were calculated on the basis of the total pollen of arboreal and terrestrial non-arboreal pollen taxa. Only those pollen taxa that occurred with a frequency of $0.5 \%$ in at least three samples were included in the numerical analyses and in the compilation of the pollen diagrams. The diagrams were generated using the TGView (version 2.0.2) software (Grimm, 2004), and the definition of local pollenzone boundaries was based on the results of a constrained incremental sum of squares cluster analysis (CONISS), using the Edwards and Cavalli-Sforza's chord distance measure in TGView version 2.0.2.

Previous study on the modern pollen rain of the Nam Co region indicated that the arboreal pollen mainly originate from long-distance transport (Lu et al., 2010). Considering the fact that the arboreal pollen taxa in our modern samples are generally less than $2 \%$, arboreal taxa were excluded from the numerical analyses in order to minimise the effects of the long-distance transported pollen component on environmental interpretations. Furthermore, pollen percentages were square-root-transformed for the numerical analyses in order to stabilise variances and to optimise the signal-tonoise ratio. Detrended correspondence analysis (DCA; Hill and Gauch, 1980) yielded turnover gradients of 1.78, 1.07, and 1.36 standard deviations (SD) for the pollen sample sets from surface sediments of large lakes, and for the modern and fossil pollen samples from Lake Donggi Cona, respectively, indicating that linearly based methods such as principal component analysis (PCA) and redundancy analysis (RDA), or non-metric methods such as non-metric multidimensional scaling (NMDS), are appropriate for these data sets.

RDA was carried out using surface pollen data from large lakes as active samples, and the surface sediment and fossil pollen data from Lake Donggi Cona as supplementary entries. Since we focused mainly on the inter-sample distances rather than on inter-species correlations, samples were centred. The forward selection option was used, together with a Monte Carlo permutation test (999 unrestricted permutations), to detect the relative weighting of environmental factors such as mean annual precipitation $\left(P_{\mathrm{ann}}\right)$ and mean July temperature $\left(T_{\text {July }}\right)$. Partial RDAs were applied to 18 surface sediment samples collected from 9 large lakes and 9 corresponding small lakes situated close to the large lakes, including $P_{\text {ann }}, T_{\text {July }}$, and square-root-transformed lake radii as environmental variables, in order to assess the potential influence of lake size. All the ordination analyses were carried out using the CANOCO software (version 4.5) for ordination and the CanoDraw software for plotting (ter Braak and Šmilauer, 2002).

As the DCA yields a $1.78 \mathrm{SD}$ for the pollen sample set from surface sediments of large lakes, unimodal methods could also be applied to this data set. weightedaveraging partial least squares (WA-PLS) models were developed for quantitative reconstructions based on modern 
pollen data collected from large lakes, associated with the inverse-distance-weighted climate data, using the $\mathrm{C} 2$ program (Juggins, 2003). The numerical relationship between modern climate data and pollen values predicted by the calibration model (in leave-one-out cross-validation) was used to select the most appropriate WA-PLS model and to help assess the performance of the calibration method.

Besides the commonly used the WA-PLS approach, multivariate regression tree (MRT) analysis, (De'ath, 2002) superimposed on an RDA (with modern data as active and fossil data as passive or supplementary samples) is another useful method for quantifying past environmental parameters (Davidson et al., 2010a, b; Wang, et al., 2012), which has been recently used to investigate European pollen-climate relationships (Salonen et al., 2012). To further compare and validation our reconstructions by the WA-PLS method, we also applied this MRT analysis in conjunction with the RDA approach to the square-root-transformed surface pollen data from large lakes and inverse-distance-weighted climate data $\left(P_{\mathrm{ann}}\right.$, which was selected by the forward selection in RDA), implemented using Brodgar 2.6.5 software (Zuur et al., 2009).

To evaluate the correlation of pollen data recovered from large and small lakes, as well as the underlying driving factor for vegetation changes, Procrustes rotation (Peres-Neto and Jackson, 2001) was used to compare numerically pairs of multivariate data sets (for application to palaeoecological data sets see Wischnewski et al., 2011), i.e. (1) the pollen assemblages in surface sediment samples from large lakes with those from corresponding small lakes, and (2) the Lake Donggi Cona fossil pollen assemblage with ostracod assemblages from Lake Donggi Cona (Mischke et al., 2010b) and fossil pollen assemblages from the nearby Lake Kuhai (Wischnewski et al., 2011). To allow statistically based comparisons of comparable data sets, the data sets were interpolated and resampled at $250 \mathrm{yr}$ intervals using the AnalySeries 2.0.4.2 software (Paillard et al., 1996). Procrustes rotation analysis and the associated PROTEST permutation test were applied to the ordination (NMDS) results. The PROTEST function in $\mathrm{R}$, which performs a random permutation test, was modified to allow restricted permutations (block resampling) for time series data (Besag and Clifford, 1989, Wischnewski et al., 2011). The vegan package (Oksanen et al., 2008) in R (R Development Core Team, 2008) was used to carry out the NMDS ordinations, Procrustes analyses, and PROTEST (Peres-Neto and Jackson, 2001).

All the numerical analysis methods involved in this study are summarised in Table 3.

\section{Results}

\subsection{Set-up and validation of modern pollen-climate calibration set from large lakes}

In total, 55 pollen taxa were identified, of which 29 taxa were included in the pollen diagram (Figs. 2 and S1). Samples from the lowland desert or steppe areas consist mainly of Artemisia and Chenopodiaceae pollen, which together generally constitute over $70 \%$ (and up to $90 \%$ ) of the total pollen assemblage, as well as a relatively large Ephedra pollen component (E. fragilis-type and E. distachya-type). In contrast, Cyperaceae pollen makes up higher percentages (20-60\%) in samples from alpine Kobresia meadows on the eastern Tibetan Plateau. The contribution of arboreal pollen taxa (i.e. Alnus, Pinus, Picea, Juniperus, Betula, and Quercus) is generally less than $2 \%$.

The Procrustes analysis between the 9 pairs of surface pollen data from large lakes and neighbouring small lakes yields a statistically significant fit. Relatively high dissimilarities, as indicated by larger residuals, are identified for Poaceae, Cyperaceae, Brassicaceae, and Potentilla-type (see Fig. S2). Slightly higher proportions of Poaceae and Brassicaceae pollen are generally recovered from the small-lake surface samples. Furthermore, the partial RDA reveals that lake size explains $7.9 \%$ of the total variance, but this is not statistically significant $(p=0.331)$ when using lake radius as an environmental variable and $P_{\text {ann }}$ and $T_{\text {July }}$ as covariables. Alternatively, $P_{\text {ann }}$ and $T_{\text {July }}$ together significantly explain $46.1 \%$ of the total variance when lake size is used as a covariable $(p<0.001)$.

As shown in Fig. 3, relatively small pollen source areas are estimated for the larger pollen grains (such as Cyperaceae and Poaceae) (Table 2). In contrast, small pollen grains such as Artemisia and Chenopodiaceae yield relatively large source areas. Taking into account the relative proportions of the different pollen taxa, pollen source areas covering distances ranging from 50 to $250 \mathrm{~km}$ from the lakes are estimated for the 53 large lakes (Fig. 31). The inverse-distanceweighted data within the pollen source areas generally indicate higher precipitation and lower temperatures than the climate data from the sampling points (Fig. 4). The difference between mean annual precipitation varies from -15 to $47 \%$, with an average of about $9 \%$ (Fig. 4a). The inverse-distanceweighted mean July temperatures are up to $2.8^{\circ} \mathrm{C}$ lower than those for the sample points (Fig. $4 \mathrm{~b}$ ). Subsequently, the reconstructions with consideration of the IDW method are ca. $30 \mathrm{~mm}$ higher than the reconstructions without IDW (see Fig. S5), further indicating the necessity of considering the pollen source area and the IDW process.

On the basis of the surface pollen data from 53 large lakes, the first two RDA axes capture $28.1 \%$ of the total variance in pollen assemblages (axis 1, 26.3\%; axis 2, $1.8 \%$ ), suggesting that only a few underlying variables dominate the data structure. The forward selection option within RDA suggests 
Table 3. Summary of statistical methods involved in this study, the employed data sets, the general purposes, the results and used programs.

\begin{tabular}{|c|c|c|c|c|}
\hline $\begin{array}{l}\text { Statistical } \\
\text { method }\end{array}$ & Data set & Purpose & Result & Program \\
\hline DCA & $\begin{array}{l}\text { Surface sediments of large lakes, } \\
\text { and for the modern and } \\
\text { fossil pollen samples from Lake } \\
\text { Donggi Cona }\end{array}$ & $\begin{array}{l}\text { To select suitable statistical } \\
\text { methods }\end{array}$ & $\begin{array}{l}\text { RDA and nMDS are appropriate } \\
\text { methods }\end{array}$ & CANOCO \\
\hline $\begin{array}{l}\text { RDA with } \\
\text { forward } \\
\text { selection }\end{array}$ & $\begin{array}{l}\text { Surface pollen data from large } \\
\text { lakes as active samples, and } \\
\text { the surface sediment and fossil } \\
\text { pollen data from Lake Donggi } \\
\text { Cona as supplementary entries }\end{array}$ & $\begin{array}{l}\text { To select suitable climate } \\
\text { parameter for } \\
\text { reconstruction }\end{array}$ & $\begin{array}{l}\text { Pollen data show more sensitive } \\
\text { to precipitation change than } \\
\text { temperature }\end{array}$ & CANOCO \\
\hline Partial RDA & $\begin{array}{l}18 \text { surface sediment samples } \\
\text { collected from } 9 \text { large lakes and } \\
9 \text { corresponding small lakes } \\
\text { situated close to the large lakes }\end{array}$ & $\begin{array}{l}\text { To assess the potential } \\
\text { influence of lake size } \\
\text { on pollen composition }\end{array}$ & $\begin{array}{l}\text { Lake size has influences on the } \\
\text { pollen assemblages in sediments }\end{array}$ & CANOCO \\
\hline WA-PLS & $\begin{array}{l}\text { Surface pollen data from large } \\
\text { lakes and fossil pollen data from } \\
\text { Lake Donggi Cona }\end{array}$ & $\begin{array}{l}\text { To perform quantitative } \\
\text { climate reconstruction }\end{array}$ & $\begin{array}{l}\text { Mean annual precipitation is } \\
\text { reconstructed }\end{array}$ & $\mathrm{C} 2$ \\
\hline MRT-RDA & $\begin{array}{l}\text { Surface pollen data from large } \\
\text { lakes and fossil pollen data from } \\
\text { Lake Donggi Cona }\end{array}$ & $\begin{array}{l}\text { To perform quantitative } \\
\text { climate reconstruction }\end{array}$ & $\begin{array}{l}\text { Mean annual precipitation is } \\
\text { reconstructed }\end{array}$ & CANOCO \\
\hline Procrustes(1) & $\begin{array}{l}\text { Fossil pollen and ostracod data } \\
\text { from Lake Donggi Cona }\end{array}$ & $\begin{array}{l}\text { To evaluate the correlation } \\
\text { of these two data sets }\end{array}$ & $\begin{array}{l}\text { Non-fit between these two } \\
\text { data sets }\end{array}$ & $\mathrm{R}$ \\
\hline Procrustes(2) & $\begin{array}{l}\text { Fossil pollen data from Lake } \\
\text { Donggi Cona and Lake Kuhai }\end{array}$ & $\begin{array}{l}\text { To evaluate the correlation } \\
\text { of these two data sets }\end{array}$ & $\begin{array}{l}\text { Significant correlation between } \\
\text { these two data sets }\end{array}$ & $\mathrm{R}$ \\
\hline
\end{tabular}

that mean annual precipitation $\left(P_{\mathrm{ann}}\right)$ is the main factor determining the pollen assemblage, which significantly $(p$ value $<0.001$ ) explains $18 \%$ of the total variance (Fig. 5a).

MRT analysis of surface pollen samples from the large lakes was performed using $P_{\text {ann }}$ as an environmental variable, yielding a tree with 4 leaves (Fig. 2). The surface pollen samples from large lakes were then classified into four groups (LSG 1-4) on the basis of MRT results. The first of these groups (LSG 1), in which $P_{\text {ann }}$ is below $170 \mathrm{~mm}$, is characterised by high percentages of Chenopodiaceae pollen $(>40 \%)$ and very low frequencies of Cyperaceae pollen. The LSG 2 group contains samples with slightly lower Chenopodiaceae content of around $30 \%$, indicating a mean annual precipitation range between 170 and $315 \mathrm{~mm}$. The LSG 3 group comprises samples from 22 lakes, for which higher precipitation $(314-490 \mathrm{~mm})$ is indicated by a reduced Chenopodiaceae content (about $10 \%$ ) as well as continuous appearance of Cyperaceae. The dominance of Cyperaceae in the LSG 4 group, in which it comprises up to $80 \%$ of the total pollen assemblage, indicates the highest mean annual precipitation conditions, with $P_{\text {ann }}$ generally greater than $490 \mathrm{~mm}$. In addition, the distribution of modern pollen samples on the
RDA bi-plot represents the $P_{\text {ann }}$ gradient identified by the MRT (Fig. 5a).

Since the RDA reveals a strong correlation between $P_{\text {ann }}$ and pollen compositions, WA-PLS models were developed to reconstruct mean annual precipitation. In an initial WA-PLS model, 4 samples with residuals twice the model root mean square error of prediction (RMSEP) were identified and excluded as outliers. A two-component WA-PLS model was then selected for $P_{\text {ann }}$ reconstructions, taking into account the low RMSEP of $98 \mathrm{~mm}$ and the high squared correlation between jackknife-predicted and observed values $\left(r_{\text {Jack }}^{2}\right)$ of 0.69 .

\subsection{Surface pollen samples from Lake Donggi Cona}

In total, 79 pollen taxa were identified in the 15 surface sediment samples from Lake Donggi Cona, of which 22 were used for numerical analysis (Fig. S2b). The first two axes of the sample-centred PCA analysis capture 36.1 and $11.9 \%$ of the total variance, respectively. Three groups can be identified along the gradient of the first axis, correlating with the spatial distributions within the lake. Group DCS-I (Donggi Cona Surface) from the eastern part of the lake lies on the upper part of the second axis owing to the low amount of 


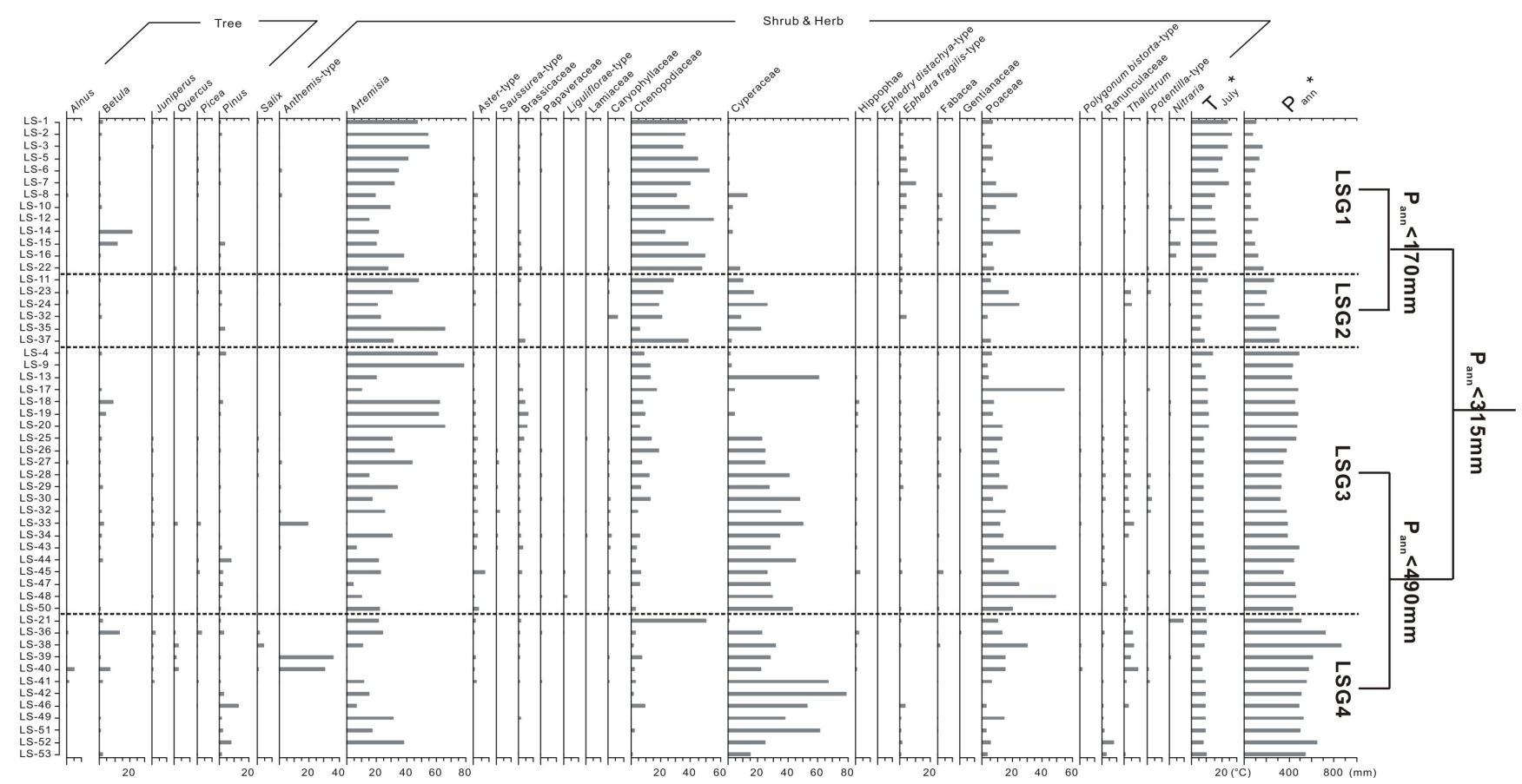

Fig. 2. Pollen spectra of surface sediment samples from large lakes together with the associated inverse-distance-weighted climate data $\left(P_{\text {ann }}^{*}\right.$ and $T_{\text {July }}^{*}$ ). A Multivariate Regression Tree (MRT) plot for surface sediment pollen data from the 53 large lakes, with the group classifications (LSG 1-4), is shown to the right of the pollen diagram.

Chenopodiaceae pollen, while group DCS-II from the central part and group DCS-III at the western end of the lake lie at either end of the first axis due to their different Cyperaceae pollen contents (Figs. 1, S1 and S3). When passively plotted on the RDA tri-plot based on the pollen data from 53 large lakes, all surface samples (except for 2 samples that fall in LSG 2 group) from Lake Donggi Cona are dispersed within the LSG 3 group (Fig. 5b), representing a mean annual precipitation between 315 and $490 \mathrm{~mm}$, and the WAPLS-derived annual precipitation results range from 320 to $402 \mathrm{~mm}$, which fit well with the inverse-distance-weighted modern climate data for Lake Donggi Cona (Figs. 2 and 8c).

\subsection{Core PG1790 from Lake Donggi Cona}

Samples from core PG1790 consist mainly of four taxa of herbaceous pollen that are common in arid and semi-arid areas, i.e. Artemisia, Chenopodiaceae, Poaceae, and Cyperaceae; these make up over $80 \%$ of the total pollen assemblage (Fig. 6). Aster-type, Thalictrum, Ephedra, Potentillatype, and Brassicaceae pollen appear continuously in moderate quantities varying between 1 and $5 \%$. The content of arboreal pollen taxa including Pinus, Picea, Alnus, Betula, and Quercus is relatively low. The fossil pollen diagram is divided into six pollen assemblage zones on the basis of the CONISS stratigraphically constrained cluster analysis ( $\mathrm{PZ}$ $1-6$, Figs. 5b and 6). The characteristic pollen taxa, inferred vegetation, and inferred precipitation are shown in Table 4.
Passively plotted on the RDA tri-plot, fossil samples mostly fall into the first three LSG groups, with no samples appearing in the LSG 4 group (Fig. 5b). Fossil samples in PZ 1 and PZ 2 are mainly located within LSG 1, with only a few samples in PZ 2 falling within LSG 2. PZ 3 and PZ 4 show rather scattered distributions between LSG 2 and LSG 3, while PZ 5 and PZ 6 fall mainly in LSG 2. It is interesting to note that the modern surface samples from Lake Donggi Cona generally concentrate in LSG 3, with the exception of two samples in LSG 2. Mean annual precipitations $\left(P_{\mathrm{ann}}\right)$ reconstructed using WA-PLS show variations ranging from about $100 \mathrm{~mm}$ during the Late Glacial period to about $400 \mathrm{~mm}$ in the early Holocene (Fig. 8).

The results of the Procrustes and PROTEST analyses are summarised in Fig. 7 and Table 5. The low PROTEST correlation coefficient (0.36) together with the high $p$ value (0.43) indicate a non-fit between the pollen and ostracod data sets from Lake Donggi Cona, which could be further inferred from the high Procrustes residuals (Fig. 7). In contrast, variations in pollen data from Lake Donggi Cona show a significant correlation with pollen data from Lake Kuhai, with a high PROTEST correlation coefficient (0.56) and low Procrustes rotation sum of squares $(0.68)$. 
Table 4. Summary of the pollen assemblages and climate reconstructions from Lake Donggi Cona over the last $>18.3$ cal. ka BP.

\begin{tabular}{|c|c|c|c|c|c|}
\hline PZ & $\begin{array}{r}\text { Depth } \\
(\mathrm{cm})\end{array}$ & $\begin{array}{r}\text { Ages } \\
(\text { cal. ka BP) }\end{array}$ & $\begin{array}{l}\text { Pollen } \\
\text { assemblages }\end{array}$ & $\begin{array}{l}\text { RDA } \\
\text { group }\end{array}$ & $\begin{array}{l}\text { WA-PLS } \\
\text { based } P_{\text {ann }}\end{array}$ \\
\hline 1 & $475-455$ & $>18.3$ & $\begin{array}{l}\text { Dominated by herbaceous taxa Artemisia and Chenopodiaceae, } \\
\text { characterised by extremely low pollen concentrations, and a high content } \\
\text { of arboreal taxa (Alnus, Pinus, Picea, Juniperus and Betula), contributing } \\
\text { up to about } 20 \% \text { of total terrestrial pollen. }\end{array}$ & LSG 1 & $\begin{array}{l}\text { Min } 108 \mathrm{~mm} \text {, } \\
\max 188 \mathrm{~mm}, \\
\text { mean } 151 \mathrm{~mm}\end{array}$ \\
\hline 2 & $455-220$ & ca. $18.3-13.1$ & $\begin{array}{l}\text { Dominated by Artemisia and Chenopodiaceae (up to } 70 \% \text { ). Poaceae and } \\
\text { Cyperaceae increased up to } 20 \text { and } 10 \% \text {, Caryophyllaceae, Thalictrum, } \\
\text { Aster-type, Brassicaceae, and Ephedra started to appear, along with a } \\
\text { reduction in arboreal taxa. }\end{array}$ & LSG $1 \& 2$ & $\begin{array}{l}\text { Min } 63 \mathrm{~mm}, \\
\max 291 \mathrm{~mm}, \\
\text { mean } 197 \mathrm{~mm}\end{array}$ \\
\hline 3 & $220-153$ & $13.1-9.5$ & $\begin{array}{l}\text { Abrupt increase in the pollen concentrations, Chenopodiaceae decreased } \\
\text { rapidly by 20-30\% and was generally replaced by Artemisia. } \\
\text { Cyperaceae increased steadily following the decrease of Brassicaceae } \\
\text { and Aster-type. Arboreal pollen reappeared at the end of this period. }\end{array}$ & LSG $2 \& 3$ & $\begin{array}{l}\text { Min } 264 \mathrm{~mm} \text {, } \\
\max 402 \mathrm{~mm} \text {, } \\
\text { mean } 334 \mathrm{~mm}\end{array}$ \\
\hline 4 & $153-112$ & $9.5-7.3$ & $\begin{array}{l}\text { Characterised by a second high pulse of arboreal pollen } \\
\text { frequencies, mainly resulting from an increasing content of Picea. } \\
\text { Artemisia decreased gradually, synchronously with increasing } \\
\text { frequencies of Chenopodiaceae. }\end{array}$ & LSG $2 \& 3$ & $\begin{array}{l}\text { Min } 158 \mathrm{~mm}, \\
\max 321 \mathrm{~mm}, \\
\text { mean } 251 \mathrm{~mm}\end{array}$ \\
\hline 5 & $112-70$ & $7.3-4.3$ & $\begin{array}{l}\text { Chenopodiaceae and arboreal pollen decreased, together, with relatively } \\
\text { high frequencies of Artemisia. Ephedra, Thalictrum, Aster-type and } \\
\text { Potentilla-type still continuing, but to a lesser extent. }\end{array}$ & LSG $2 \& 3$ & $\begin{array}{l}\text { Min } 281 \mathrm{~mm} \text {, } \\
\max 353 \mathrm{~mm}, \\
\text { mean } 324 \mathrm{~mm}\end{array}$ \\
\hline 6 & $70-16$ & $4.3-1.1$ & $\begin{array}{l}\text { Dominated by Artemisia, Chenopodiaceae, Poaceae and Cyperaceae, } \\
\text { together with slightly higher frequencies of Brassicaceae and Ephedra } \\
\text { fragilis-type. }\end{array}$ & LSG 2\&3 & $\begin{array}{l}\text { Min } 221 \mathrm{~mm} \text {, } \\
\max 325 \mathrm{~mm} \text {, } \\
\text { mean } 281 \mathrm{~mm}\end{array}$ \\
\hline
\end{tabular}

\section{Discussion}

\subsection{Accuracy of pollen-based climate reconstructions from large lakes}

We propose that the accuracy of pollen-based climate reconstruction from large lakes will improve when the effects of (1) pollen source area and (2) within-lake variations in pollen assemblage are taken into account, and when (3) pollen data are validated with other proxies and other sites.

1. Pollen source areas for sites in pollen-climate calibration sets. Pollen source areas are assumed to depend mainly on the size of the lake basin and the species-specific dispersal and depositional characteristics of pollen grains (e.g. Prentice, 1985, 1987; Sugita, 1993; Borström et al., 2008). Our partial RDA, based on pollen data from 9 pairs of neighbouring large and small lakes, reveals an insignificant but consistent influence from lake size, explaining $7.9 \%$ out of $48.1 \%$ of the explained variance in pollen assemblage. Furthermore, our numerical comparison of the inter-species relationships in small and large lakes reveals higher residuals for taxa with large pollen grains (Cyperaceae, Poaceae) than for those with small grains (Artemisia, Chenopodiaceae). This is in agreement with the theory of pollen dispersal that the smaller the grain the larger the source area (pollen grain sizes, from large to small, are Cyperaceae, Poaceae, Chenopodiaceae, and Artemisia; Fig. 3a-k) (Sugita, 1993). Hence the size of pollen source area for a lake depends not only on the size of the lake but also on the species composition in the surrounding vegetation. This conclusion is supported by the results from our source area estimations for the 53 surface sediment samples presented in Fig. 31, where only a loose positive relationship can be inferred between the size of the lake basin and the source area. Both variations in lake size through time and changes in the pollen composition may therefore affect a lake's pollen source area size, but these factors have rarely been considered when inferring quantitative climate variations from lake pollen records on Tibetan Plateau (Shen et al., 2006; Herzschuh et al., 2009; Lu et al., 2011).

RDA based on the calibration data set reveals that precipitation is the major constraining variable for pollen spectra within the study region, which confirms the results of previous studies in central Asia (Shen et al., 2006; Herzschuh et al., 2010). To allow for the concept of pollen source area when setting up the pollen-climate calibration model, we included only pollen spectra from large lakes and used 

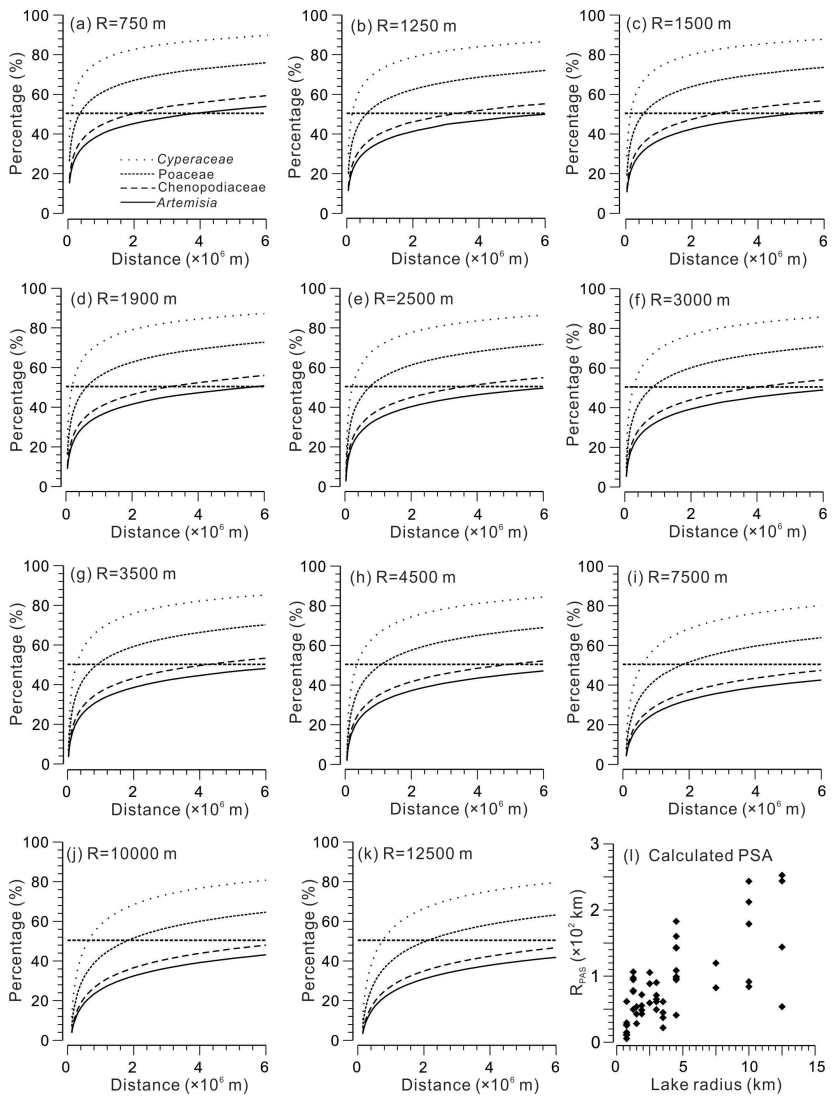

Fig. 3. (a-k): establishment of pollen source areas for the four major pollen types (Artemisia, Chenopodiaceae, Poaceae, and Cyperaceae) using various lake sizes (radii ranging from 750 to $12500 \mathrm{~m}$ ), showing the changes to the proportion of pollen loading in the lake ( $y$ axes - percentages) with increasing distance from the lake ( $x$ axes - metres) (horizontal lines indicate the $50 \%$ levels). (l): correlation of the calculated pollen source area radius with the lake radius for 53 surface sediment pollen samples from large lakes.

distance-weighted $P_{\text {ann }}$ values as climate data (Table 1). The two-component WA-PLS model yields a slightly higher RMSEP as a percentage of the total gradient $(12.1 \%$, vs. $7.2 \%$ in Shen et al., 2006, based on soil samples, and vs. $10.6 \%$ in Herzschuh et al., 2010, based predominantly on small lakes), which may originate from the generally higher noise-to-signal ratio in large lakes due to the higher long-distance component in such lakes. For example, the smaller pollen grains (e.g. Artemisia, Chenopodiaceae; see Table 2) could be easily suspended and transported over long distances, reaching the central part of large lakes. In other words, the pollen assemblages recovered from large lakes contain relatively higher regional noise, which possibly causes the higher RMSEP in our large lake calibration data set compared to the previously published data sets of surface soil or small lakes. Thus, when applying pollen-climate correlations based on
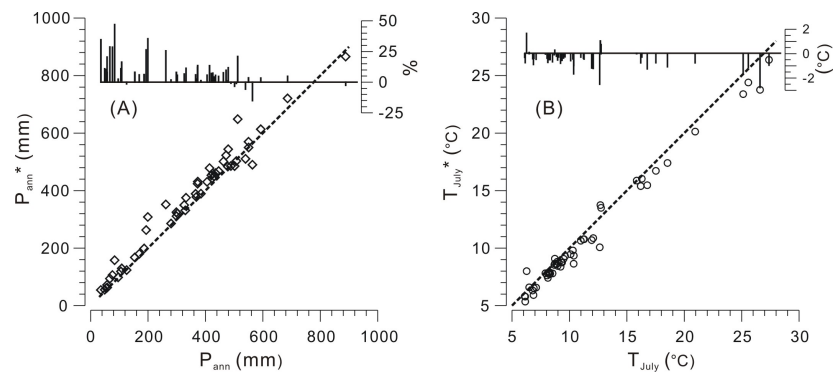

Fig. 4. Plot of inverse-distance-weighted climate parameters within individual pollen source area ( $y$ axis) against climate data collected from the sampling point ( $x$ axis): (A) mean annual precipitation; (B) mean July temperature. The vertical bar plot inserts indicate the differences in precipitation (percentages) and temperature (degrees).

samples with much smaller pollen source areas directly to pollen records recovered from large lakes, the RMSEP obtained from the modern calibration set will underestimate the real error ranges of the reconstruction, which is influenced by the pollen transportation process rather than a systematic offset. Furthermore, higher precipitation reconstructed with consideration of the pollen source area (Fig. S5) confirms the influences of lake size on the climate reconstruction, i.e. that to treat a lake as a point is not suitable for pollen related studies.

2. Patterns of within-lake variability for pollen spectra. Pollen grains deposited in lakes are always assumed to have originated mainly from the aerial pollen component. Large pollen grains are assumed to have a lower dispersibility than small grains (Fig. 3a-k) and hence to make up a higher proportion of the pollen in sediments that are close to the lake margins than are from the lake centre. This is supported by Luly (1997), who found an increasing proportion of Chenopodiaceae pollen in pollen traps towards the central part of Lake Tyrrell, in Australia. Concentric distribution patterns have also been reported for the herbaceous pollen proportions in Lake Dianchi, Yunnan Province, China (Sun and Wu, 1987). However, only the patterns have hitherto been described, while the influences that these within-lake variations have on pollen-based climate calibrations have not previously been evaluated. On the other hand, the redeposition of pollen grains in lakes also affects the pollen composition, especially for the shallower lakes (Bonny, 1978). The importance of pollen redeposition has also been demonstrated in sediment trap studies at Frains Lake and Sayles Lake, Michigan, which indicated that up to $80 \%$ of the pollen could have been reworked from the lake sediment and subsequently redeposited (Davis, 1968, 1973). Pollen redeposition has been reported to be negligible in lakes with steep-sided basins, regardless of 

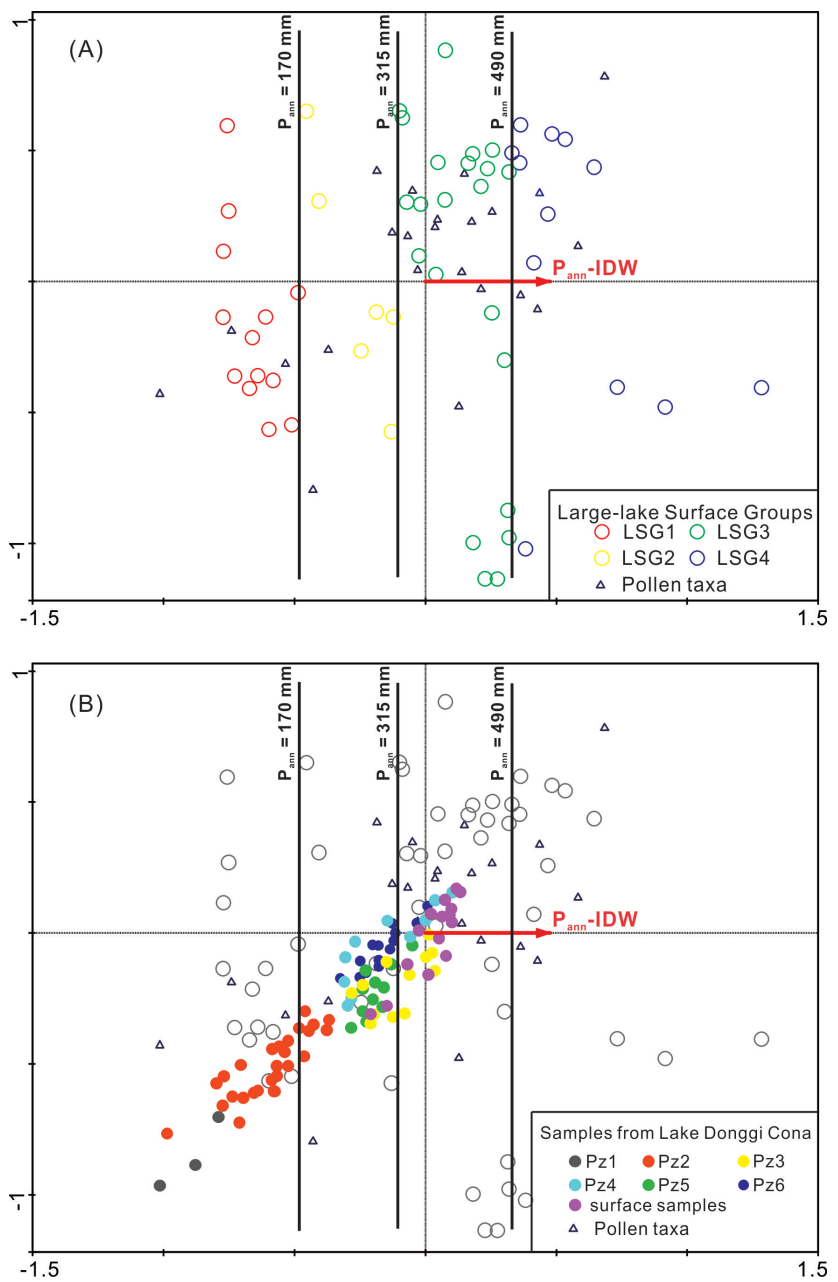

Fig. 5. (A) RDA tri-plot of surface pollen assemblages from 53 large lakes, constrained by inverse-distance-weighted mean annual precipitation $\left(P_{\mathrm{ann}}\right)$; samples have been classified using different colours indicating different groups identified by MRT. (B) Fossil and modern pollen samples from Lake Donggi Cona are supplementary objects on the RDA plot of (A): the bold black lines and associated precipitation results indicate the thresholds derived from the MRT analysis.

the lake basin size (Pennigston, 1974; Bonny, 1976). WA-PLS-derived precipitation figures for the surface sediment samples from Lake Donggi Cona vary between 347 and $452 \mathrm{~mm}$, showing a decreasing trend towards the lake centre (Figs. 8c and S4). Taking into account the steep-sided basin structure of Lake Donggi Cona, such variation in precipitation reconstruction is therefore likely to be caused by wind-driven transportation processes rather than by redeposition processes within the lake.

Fluvial input is another potential source of pollen in the sediments of lakes. On the basis of pollen investigations in Lake Malawi and its catchment areas, Debusk (1997) concluded that fluvial supply of pollen is of the same order of magnitude as aerial input. Xu et al. (2005) reported variations in both pollen concentrations and pollen assemblages within Lake Daihai (Inner Mongolia, China). They found higher concentrations of pollen in sediments of alluvial origin, and a good correlation between the pollen composition in the sediments and the composition of vegetation within the catchments of the inflows, from which they proposed that the pollen were primarily river-transported. Investigations by Huang et al. (2004) of surface pollen samples from Bosten Lake in western China also revealed slight within-lake variations. Pollen grains of Picea and Juniperus were found to have been mainly river-transported to lowland desert lakes in Inner Mongolia from the nearby Qilian Mountains (Zhu et al., 2002). Similarly, at Lake Donggi Cona we found the highest Cyperaceae pollen values at the inflows, which we assume originated from the Kobresia meadows in the mountains and from wetland vegetation drained by the river. On the other hand, the two samples collected from close to the Lake Donggi Cona outflow were separated by PCA from the other samples, which had possibly also been influenced by the outflow as a result of selective loss of larger pollen grains (e.g. Cyperaceae). Hence, fluctuations in lake water level and the resulting changes in shoreline location, as well as the position and strength of discharges into the lake, are likely to influence the distribution of pollen within large lakes. In addition, an abrupt non-climate-related lake level change, i.e. tectonically driven lake opening, would also lead to changes in pollen assemblages through the variation in lake size, which may in turn lead to false interpretation of the pollen sequence.

3. Evaluation of climate reconstructions. We have aimed to differentiate the regional climate signal from local ecological/environmental noise by means of a proxy-to-proxy and site-to-site evaluation of the original proxy data, as well as by applying two different calibration methods. Aside from pollen, a variety of other proxies are commonly used for environmental reconstructions, among which ostracod assemblages on the Tibetan Plateau are assumed to primarily reflect limnological changes such as water depth and salinity (Mischke et al., 2007, 2010a, b). We interpret the non-fit of the pollen data with the ostracod data obtained from the same core (thereby excluding the influence of age-depth correlations) as indicating that the pollen data are more likely to reflect a terrestrial signal that was driven primarily by the climate than within-lake changes or variations in the fluvial input. That the pollen signal is regionally consistent is further confirmed by the significant fit between the pollen data from Lake Donggi Cona and pollen data from Lake Kuhai, $50 \mathrm{~km}$ away (Fig. 7b; 


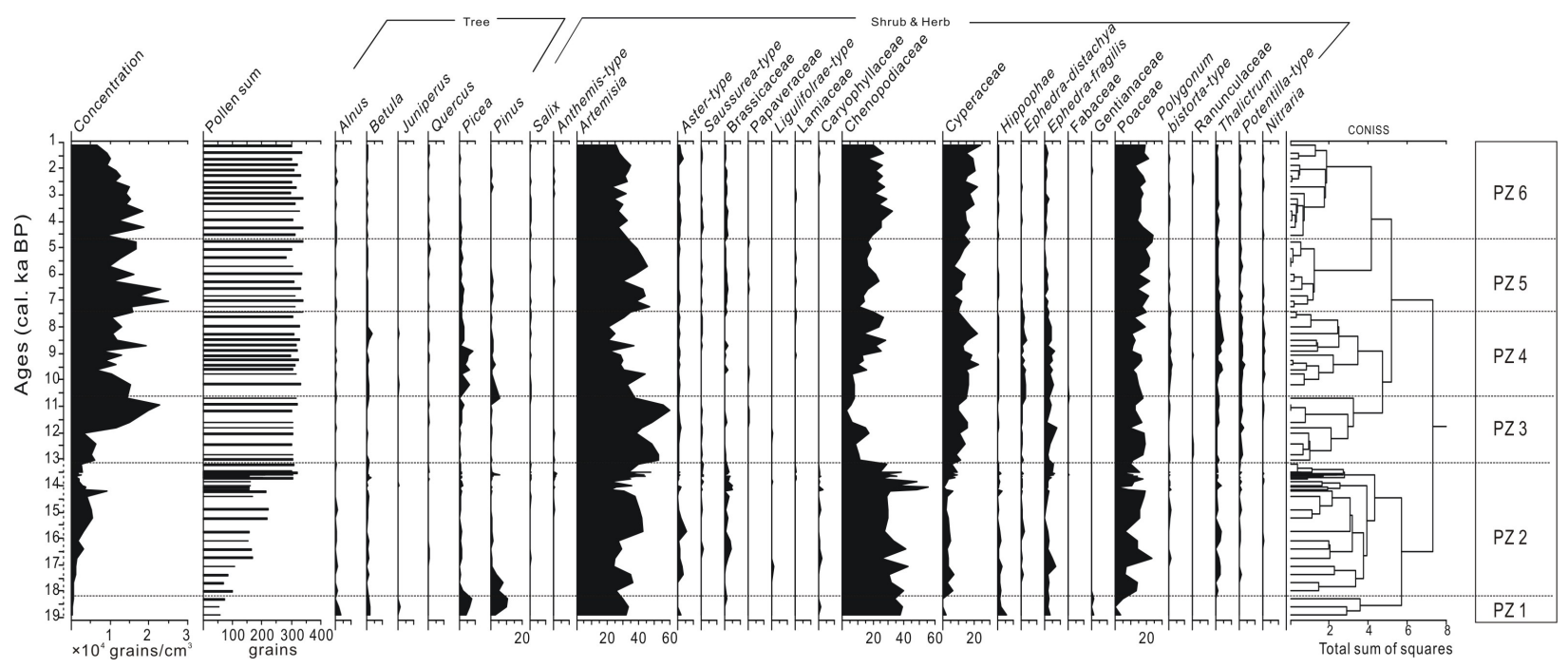

Fig. 6. Stratigraphic diagram of fossil pollen results from Lake Donggi Cona, together with pollen assemblage zones (PZ 1-6) defined by CONISS.

Table 5). According to recent organic geochemical and sedimentological evidence, Lake Donggi Cona became an open-water system during the late Holocene (around 6.8 cal. ka BP) (Aichner et al., 2012; Opitz et al., 2012). Such hydrological change could have serious effects on the aquatic ecosystems (in particular ostracods here), which may have led to the substantial discrepancies between the ostracod and pollen records as indicated by the obvious different trends after 6 cal. ka BP (Fig. 7a). On the other hand, the pollen records mainly reflect regional signals, which may not have been affected by such hydrological change, showing generally consistent patterns between Lake Donggi Cona and Lake Kuhai (Fig. 7b). Therefore, our fossil pollen record here is more appropriate to infer the past climate changes than ostracod.

The quantitative precipitation reconstruction obtained by the WA-PLS method was validated by the combined MRT-RDA calibration method (Davidson et al., 2010a, b). The semi-quantitative results obtained vary between about $100 \mathrm{~mm}$ and $400 \mathrm{~mm}$. Both the range and the pattern through time thus obtained are almost identical to the WA-PLS-based reconstructions despite the two different basic principles of the methods: WAPLS assumes a unimodal pollen-climate response, while RDA performs better with linear relationships (Fig. 8) (Birks et al., 2010). The fact that the reconstructions are independent of the calibration method used indicates the robustness of our approaches.

\subsection{Late Glacial and Holocene climate evolution of the Lake Donggi Cona area}

To help decide whether the climate signals inferred from the Lake Donggi Cona pollen record are of local or of regional validity, we compared our results to other records from the eastern Tibetan Plateau and attempted to identify the driving forces behind the reconstructed climate changes (Fig. 8).

We have inferred a low vegetation cover in the Lake Donggi Cona area, as indicated by the high amount of pollen that may have undergone long-distance transport and by the extremely dry conditions $\left(P_{\mathrm{ann}} \sim 150 \mathrm{~mm}\right.$ ) from the basal sediments in our core, which accumulated during, or soon after, the LGM. These results are in agreement with previously reconstructed precipitation results from the Luanhaizi (Herzschuh et al., 2010) and Ren Co lakes (Tang et al., 2004) on the eastern Tibetan Plateau, where precipitation was reconstructed to be about half the present level. Additional lacustrine records from the eastern Tibetan Plateau, such as those from Ximen Co Lake and Lake Naleng on the eastern Tibetan Plateau (Zhang and Mischke, 2009; Kramer et al., 2010a) and Lake Shudu from Yunnan Province in southwestern China (Cook et al., 2011), indicate that lacustrine sedimentation in many glacial basins started immediately after the LGM. As summarised in Herzschuh (2006), only a few lakes existed continuously during the LGM in the present-day monsoonal areas of central Asia due to the extremely low effective moisture, which resulted from the low temperatures of the Northern Hemisphere (Dansgaard et al., 1993) and the shutdown of the Asian monsoonal system.

Thereafter, slightly wetter Late Glacial conditions $\left(P_{\mathrm{ann}} \sim 200 \mathrm{~mm}\right)$ are reconstructed, which were terminated by an abrupt reversion to extremely dry conditions. Generally increasing trends in precipitation after the LGM have also 
Table 5. Summary of Procrustes rotation and PROTEST diagnostics.

\begin{tabular}{|c|c|c|c|c|}
\hline Data & $\begin{array}{r}\text { Procrustes } \\
\text { rotation } \\
\text { sum of } \\
\text { squares }\end{array}$ & RMSE & $\begin{array}{r}\text { PRO- } \\
\text { TEST } \\
(r)\end{array}$ & $\begin{array}{r}p \\
\text { values }\end{array}$ \\
\hline $\begin{array}{l}\text { Lake Dongi Cona pollen vs. } \\
\text { Lake Donggi Cona ostracod }\end{array}$ & 0.86 & 0.11 & 0.363 & 0.43 \\
\hline $\begin{array}{l}\text { Lake Dongi Cona pollen vs. } \\
\text { Lake Kuhai pollen }\end{array}$ & 0.68 & 0.10 & 0.56 & 0.01 \\
\hline
\end{tabular}

been reconstructed on the basis of pollen records from Lake Kuhai (Wischnewski et al., 2011), Lake Koucha (Herzschuh et al., 2009), Lake Yidun (Shen et al., 2006), Lake Luanhaizi (Herzschuh et al., 2010), and Ren Co Lake (Tang et al., 2004), which are on the eastern Tibetan Plateau, and have been further confirmed by climate indices reviewed in Herzschuh (2006) and Wang et al. (2010). Following an increase in solar insolation, meltwater from glaciers and frozen ground probably contributed to an increase in the moisture available to vegetation. Taking into account the dating uncertainties, the reversion from the first wet period after the LGM may be stratigraphically consistent with "Heinrich event 1 " in the North Atlantic region (Broecker et al., 1992). This may indicate that the climate on the Tibetan Plateau during the early part of the Late Glacial was influenced by cold and dry westerly air masses originating from the North Atlantic region, as has been previously suggested from a review of the loess records (Vandenberghe et al., 2006).

According to palynological studies from the nearby Lake Kuhai (Wischnewski et al., 2011) and Lake Koucha (Herzschuh et al., 2009), the abrupt decrease in Chenopodiaceae and increase in Artemisia pollen at about $14.5 \mathrm{cal}$. ka BP indicate the start of a period temporally consistent with the Bølling/Allerød event. Identical patterns are also found in the pollen sequences of Lake Donggi Cona, dated to about 13.5 cal. ka BP. We assume that the difference of about $1000 \mathrm{yr}$ results from local scale and temporal variations in the hard water effect, and hence the radiocarbon ages from the bottom part of the core may be less reliable. Another reversion to dry conditions in the Lake Donggi Cona area at about 12 cal. ka BP is temporally correlated to the Younger Dryas cold event. However, owing to the limited resolution of our pollen record, only two samples were recovered during this period, which is therefore not visible in the smoothed precipitation reconstruction. Records from other nearby lakes, e.g. from Qinghai Lake (Shen et al., 2005), Lake Kuhai (Mischke et al., 2009), and Lake Koucha (Mischke et al., 2008), reveal identical wet Bølling/Allerød and dry Younger Dryas events, albeit with minor temporal inconsistencies.

The highest pollen-derived annual precipitation (up to $400 \mathrm{~mm}$ ) was reconstructed for the early Holocene, which has also been reported from other sites on the Tibetan Plateau (see syntheses in Morrill et al., 2003; Herzschuh, 2006; Zhang and Mischke, 2009; Wang et al., 2010; Wischnewski et al., 2011). Although the reconstructed precipitation values for this period at Lake Yidun (Shen et al., 2006), Lake Luanhaizi (Herzschuh et al., 2010) and Ren Co Lake (Tang et al., 2004) were not the maximum, they are consistently inferred to have been significantly higher (by $\sim 50 \%$ ) than in the Late Glacial. The drivers behind this wet phase were further increases in Northern Hemisphere summer solar insolation, increased meltwater from glaciers and frozen ground, and enhanced precipitation due to an intensified Asian summer monsoon (ASM) (Wang et al., 2005).

The annual precipitation inferred from the Lake Donggi Cona pollen record subsequently decreased to around $200 \mathrm{~mm}$, resulting mainly from the increase in Chenopodiaceae pollen. Records from nearby lakes also indicate relatively low precipitation (Herzschuh et al. 2009; Wischnewski et al., 2011), but the signal is not as pronounced as at Lake Donggi Cona. This is probably due to the fact that the pollen loadings in the large Lake Donggi Cona derive from a larger source area at lower elevation, including a relatively high proportion of desert areas in the lowlands, e.g. the Qaidam Basin. Quantitative reconstructions from Lake Donggi Cona are consequently likely to overestimate the precipitation signal in the direct vicinity of the lake. The ASM (mainly the Indian summer monsoon) retreated after the early Holocene following changes in Northern Hemisphere insolation, as revealed by marine records from the Arabian Sea (e.g. Overpeck et al., 1996), stalagmites (e.g. in the Dongge Cave in south-western China (Wang et al., 2005) and in the Qunf Cave in southern Oman (Fleitmann et al., 2007)), and synthetic moisture indices (Herzschuh, 2006; Wang et al., 2010), resulting in reduced monsoonal precipitation. Lake Donggi Cona and the two nearby lakes, Lake Kuhai and Lake Koucha, generally show consistent patterns in the variation of pollen-based precipitation that are much more pronounced than the other records (Fig. 8), which may be due to the greater influence of glaciers in the Anemaqin mountain range.

Interestingly, the Lake Donggi Cona pollen record reveals a second wet period between about 7 and $4.5 \mathrm{cal}$. ka BP, with $P_{\text {ann }}$ around $340 \mathrm{~mm}$, which has also been found in various other climate reconstructions based on pollen records, e.g. at Lake Koucha (Herzschuh et al., 2009), Lake Kuhai (Wischnewski et al., 2011), Lake Naleng (Kramer et al., 2010b), and the no. 2 pit peat section (Yan et al., 1999). Over the same time period, maximum levels of precipitation are reconstructed from Lake Yidun (Shen et al., 2006), Lake Luanhaizi (Herzschuh et al., 2010), Lake Hidden, and Ren Co Lake (Tang et al., 2004). Other (non-pollen) studies from the eastern Tibetan Plateau and the Zoigê Plateau, e.g. stable carbon-isotope records from the Hongyuan peat section (Hong et al., 2005), and multi-proxy results from Qinghai Lake (Shen et al., 2005), reveal identical patterns. Temporally, this second wet stage is synchronous with the 


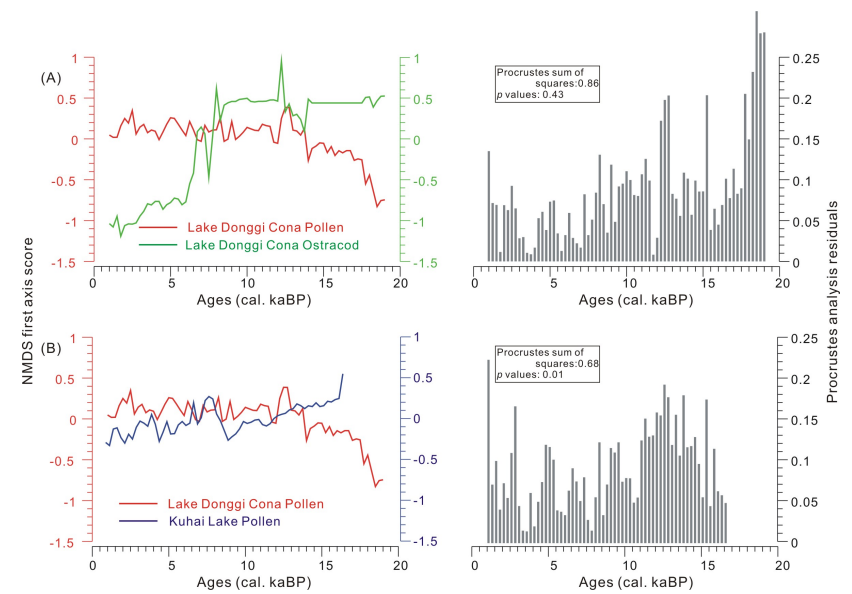

Fig. 7. Non-metric multidimensional scaling (NMDS) axis 1 scores (left) and diagram of Procrustes analysis results (right) comparing pollen and ostracod data from Lake Donggi Cona (A), and comparing pollen data from Lake Donggi Cona with data from Lake Kuhai (B). The analyses were based on data sets harmonised over $250 \mathrm{yr}$ intervals.

intensification of the EASM, revealed by a synthesis of moisture records from the monsoonal central Asia region (Wang et al., 2010), which indicates that Holocene climate changes affecting the eastern Tibetan Plateau could also, to some extent, have been influenced by the EASM system.

The late Holocene (4.5-0 cal. ka BP) shows relatively steady dry conditions that may have resulted from a further retreat of the ASM (Wang et al., 2010), which is also consistent with a phase of enhanced aeolian activity at the Donggi Cona region (IJmker et al., 2012; Stauch et al., 2012). Apart from reducing precipitation at Lake Hidden, a gradually increasing moisture trend after 3.5 cal. ka BP can be identified in the WA-PLS-reconstructed precipitation results, reflecting the increasing Cyperaceae pollen component. An expansion of Kobresia meadows in the north-eastern Tibetan Plateau is described from the two neighbouring sites at Lake Kuhai (Wischnewski et al., 2011) and Lake Koucha (Herzschuh et al., 2009), as well as in pollen records from numerous peat sections near the Nianbaoyeze Mountains (Schlütz and Lehmkuhl, 2009), indicating either more effective moisture availability or greater impact from grazing. Herzschuh et al. (2011) argued that the Holocene vegetation changes, especially the mid-Holocene extension of Kobresia meadow, can be partly attributed to the higher atmospheric $\mathrm{CO}_{2}$ levels that were present during the early Holocene based on the BIOME4 global vegetation modelling results.

\section{Conclusions}

Through investigations and numerical analyses of various surface sediment samples collected from large and small lakes, we have attempted to improve the current understand-

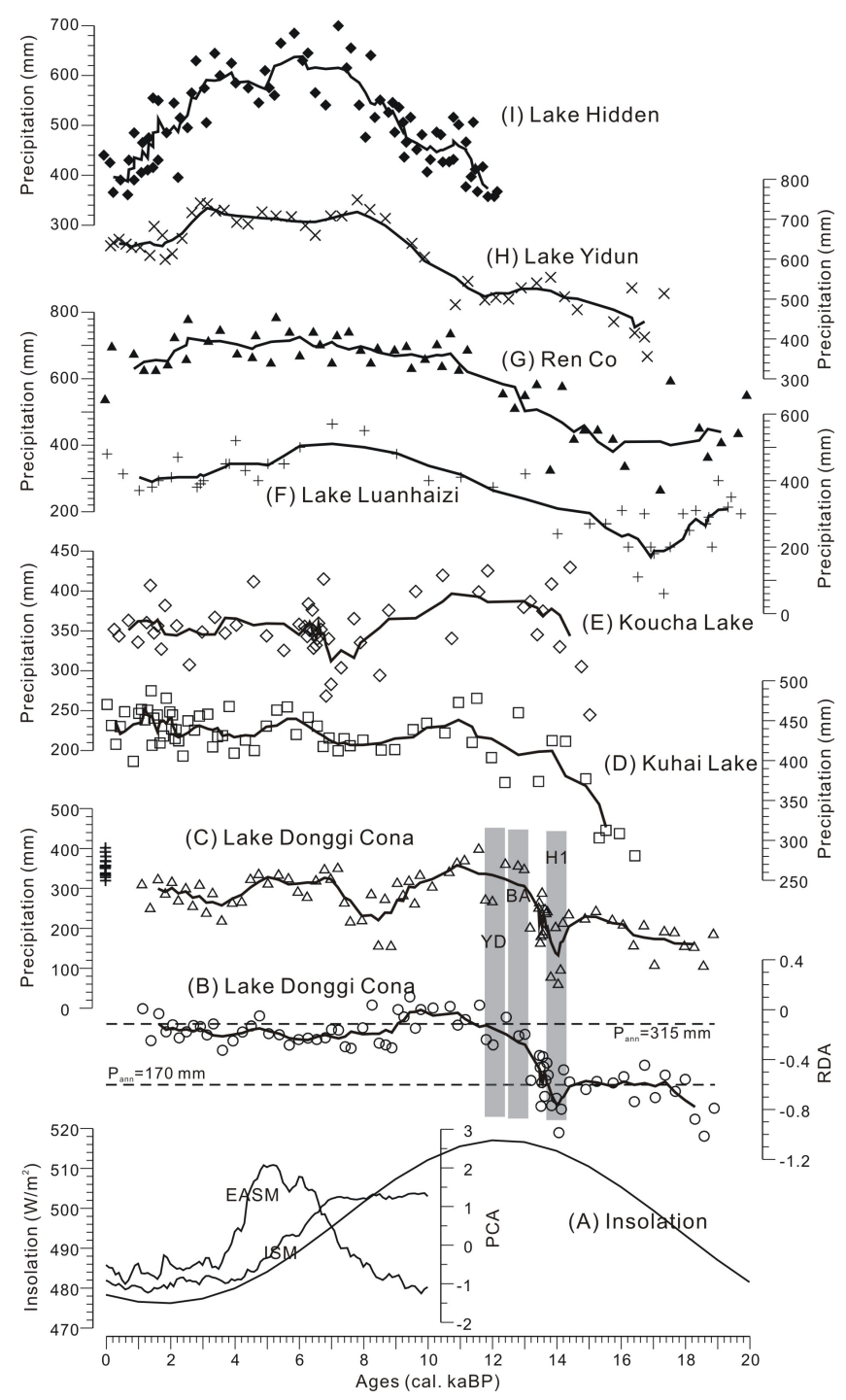

Fig. 8. (A): summer (June) solar insolation at $35^{\circ} \mathrm{N}$ (after Laskar et al., 2004) and Asian summer monsoon indices (after Wang et al., 2010). (B): first RDA axis scores from Lake Donggi Cona, together with the thresholds derived from the MRT analysis (dashed lines). (C-E): WA-PLS-reconstructed mean annual precipitation for Lake Donggi Cona (crosses indicate results from surface sediment samples DCS 1-15), Lake Koucha (after Herzschuh et al., 2009), and Lake Kuhai (after Wischnewski et al., 2011). (F-I): quantitatively reconstructed precipitation based on pollen data from Lake Luanhaizi (after Herzschuh et al., 2010), Ren Co Lake (after Tang et al., 2004), Lake Yidun (after Shen et al., 2006), and Lake Hidden (after Tang et al., 2004), on the eastern Tibetan Plateau. All fitting lines are based on LOESS smoothing; H1, BA, and YD represent Heinrich event 1, Bølling/Allerød and Younger Dryas respectively. 
ing of pollen-based climate reconstructions for large lakes, in particular with respect to pollen source areas, within-lake variability in pollen assemblages, and multi-proxy and multisite validation of the reconstruction models. Generally, we are now able to obtain more realistic climate reconstructions from large lakes, and to reduce the discrepancies caused by the application of different proxies.

Multivariate regression tree and redundancy analyses, together with WA-PLS, have been used to reconstruct precipitation in the Lake Donggi Cona area since the Last Glacial Maximum, revealing fluctuations in annual precipitation that range from about $150 \mathrm{~mm}$ during the Last Glacial Maximum to a peak of about $400 \mathrm{~mm}$ during the early Holocene. Climate changes over the north-eastern Tibetan Plateau were triggered by variations in Northern Hemisphere insolation and primarily influenced by deglaciation and fluctuations in the intensity of the Asian summer monsoon, as well as by the westerlies derived from the North Atlantic Ocean. However, future investigations and integrations of proxy data would be necessary to identify the causes of the different behaviours between lake level and pollen-based regional precipitation changes.

\section{Supplementary material related to this article is available online at http://www.clim-past.net/10/21/2014/ cp-10-21-2014-supplement.pdf.}

Acknowledgements. The authors would like to thank Xiaolong Liu and Shupeng Yin for their assistance during fieldwork. We are grateful to Yan Zhao (Lanzhou University), Jian Ni (AWI), Dieter Demeske (Free University Berlin) and Qingfeng Jiang (Nantong University) for providing us with the raw modern pollen data. We also thank Joel Guiot, Thomas Giesecke and an anonymous reviewer for their constructive comments. Y. Wang's doctoral research is funded by the "Helmholtz - China Scholarship Council (CSC) Young Scientist Fellowship" (no. 2008491101). The research was supported by the German Research Foundation (Deutsche Forschungsgemeinschaft, DFG).

Edited by: J. Guiot

\section{References}

Aichner, B., Herzschuh, U., Wilkes, H., Schulz, H., Wang, Y. B., Plessen, B., Mischke, S., Diekmann, B., and Zhang, C. J.: Ecological development of Lake Donggi Cona, north-eastern Tibetan Plateau, since the late glacial on basis of organic geochemical proxies and non-pollen palynomorphs, Palaeogeogr. Palaeocl., 313-314, 140-149, 2012.

An, Z. S., Porter, S. C., Kutzbach, J. E., Wu, X. H., Wang, S. M., Liu, X. D., Li, X. Q., and Zhou, W. J.: Asynchronous Holocene optimum of the East Asian monsoon, Quaternary Sci. Rev., 19, 743-762, 2000.

Anderson, S. T.: The relative pollen productivity and pollen representation of north European trees, and correction factor for tress pollen spectra, Danmarks Geologiske Undersoegelse, Raekke, 2 , 1-99, 1970.

Besag, J. and Clifford, P.: Generalized Monte Carlo significance tests. Biometrika, 76, 633-642, 1989.

Beug, H. J.: Leitfaden der Pollenbestimmung für Mitteleuropa und angrenzende Gebiete, Verlag Dr. Friedrich Pfeil, München (Germany), 2004.

Birks, H. J. B.: The use of pollen analysis in the reconstruction of past climates: a review, in: Climate and History, edite by: Wigley, T. M. L., Ingram, M. J., and Farmer, G., Cambridge University Press, Cambridge, 111-138, 1981.

Birks, H. J. B.: Quantitative palaeoenvironmental reconstructions from Holocene biological data, in: Global Change in the Holocene, edited by: Mackay, A. W., Battarbee, R. W., Birks, H. J. B., and Oldfield, F., Arnold London, 342-357, 2003.

Birks, H. J. B. and Seppä, H.: Pollen-based reconstructions of lateQuaternary climate in Europe - progress, problems, and pitfalls, Ac. Palaeobot., 44, 317-334, 2004.

Birks, H. J. B., Heiri, O., Seppä, H., and Bjune, A. E.: Strengths and weaknesses of quantitative climate reconstructions based on Late-Quaternary biological proxies, Open Ecol. J., 3, 68-110, 2010.

Bonny, A. P.: Recruitment of pollen to the seston and sediment of some lake district lakes, J. Ecol., 64, 859-887, 1976.

Bonny, A. P.: The effect of pollen recruitment processes on pollen distribution over the sediment surface of a small lake in Cumbria, J. Ecol., 66, 385-416, 1978.

Böhner, J.: Advancements and new approaches in climate spatial prediction and environmental modeling. Arbeitsberichte des Geographischen Institutes der Humboldt - Universität zu Berlin, 109, 49-90, 2005.

Böhner, J.: General climatic controls and topoclimatic variations in Central and High Asia, Boreas, 35, 279-295, 2006.

Böhner, J. and Antonic, O.: Land-surface parameters specific to Topo-Climatology, in: Geomorphometry: Concepts, Software, Applications, edited by: Hengl, T. and Reuter, H. I., Elsevier, Amsterdam, 195-226, 2008.

Borström, A., Nielsen, A. B., Gaillard, M. J., Hjelle, K., Mazier, F., Binney, H., Bunting, J., Fyfe, R., Meltsov, V., Poska, A., Räsänen, S., Soepboer, W., Stedingk, H., Suutari, H., and Sugita, S.: Pollen productivity estimates of key European plant taxa for quantitative reconstruction of past vegetation: A review, Veg. Hist. Archaeobot., 17, 461-478, 2008.

Broecker, W., Bond, G., Klas, M., Clark, E., and McManus, J.: Origin of the northern Atlantic Heinrich events, Clim. Dynam., 6, 265-273, 1992.

Bronk Ramsey, C.: Bayesian analysis of radiocarbon dates, Radiocarbon, 51, 337-360, 2009.

Bunting, M. J. and Middleton, R.: Modelling pollen dispersal and deposition using HUMPOL software: simulating wind roses and irregular lakes, Rev. Palaeobot. Palyno., 134, 185-196, 2005

Chen, Y., Ni, J., and Herzschuh, U.: Quantifying modern biomes based on surface pollen data in China, Global Planet. Change, 74, 114-131, 2011.

Cook, C. G., Jones, R. T., Langdon, P. G., Leng, M. J., and Zhang, E. L.: New insights on Late Quaternary Asian palaeomonsoon variability and the timing of the Last Glacial Maximum in southwestern China, Quaternary Sci. Rev., 30, 808-820, 2011. 
Dansgaard, W., Johnsen, S. J., Clausen, H. B., Dahl-Jensen, D., Gundestrup, N. S., Hammer, C. U., Hvidgerg, C. S., Steffensen, J. P., Sveinbjornsdottir, A. E., Jouzel, J., and Bond, G.: Evidence for general instability of past climate from a 250 -kyr ice-core record, Nature, 364, 218-220, 1993.

Davidson, T. A., Sayer, C. D., Langdon, P. G., Burgess, A., and Jackson, M.: Inferring past zooplanktivorous fish and macrophyte density: Application of a new regression tree model, Freshwater Biol., 55, 584-599, 2010a.

Davidson, T. A., Sayer, C. D., Perrow, M., Bramm, M., and Jeppesen, E.: The simultaneous inference of zooplanktivorous fish and macrophyte density from sub-fossil cladoceran assemblages: A multivariate regression tree approach, Freshwater Biol., 55, 546564, 2010b.

Davis, M. B.: On the theory of pollen analysis, Am. J. Sci., 261, 897-912, 1963.

Davis, M. B.: Pollen accumulation rates at Rogers Lake, Connecticut during late- and post-Glacial time, Rev. Palaeobot. Palyno., 2, 219-230, 1967.

Davis, M. B.: Pollen grains in lake sediments: redeposition caused by seasonal water circulation, Science, 162, 796-799, 1968.

Davis, M. B.: Redeposition of pollen grains in lake sediment, Limno. Oceanogr., 18, 44-52, 1973.

De'ath, G.: Multivariate regression trees: A new technique for modeling species - environment relationships, Ecology, 83, 11051117, 2002.

Debusk, G. H.: The distribution of pollen in the surface sediments of Lake Malawii, Africa, and the transport of pollen in large lakes, Rev. Palaeobot. Palyno., 97, 123-153, 1997.

Dietze, E., Wünnemann, B., Diekmann, B., Aichner, B., Hartmann, K., Herzschuh, U., Ijmker, J., Jin, H., Kopsch, C., Lehmkuhl, F., Li, S. J., Mischke, S., Niessen, F., Opitz, S., Stauch, G., and Yang, S.: Basin morphology and seismic stratigraphy of Lake Donggi Cona, north-eastern Tibetan Plateau, China, Quaternary Int., 218, 131-142, 2010.

Fægri, K. and Iversen, J.: Textbook of Pollen Analysis, 4th edition. The Blackwell Press, New Jersey, 69-89, 1989.

Fleitmann, D., Burns, S. J., Mangini, A., Mudelsee, M., Kramers, J., Villa, I., Neff, U., Al-Subbary, A. A., Buettner, A., Hippler, D., and Matter, A.: Holocene ITCZ and Indian monsoon dynamics recorded in stalagmites from Oman and Yemen (Socotra), Quaternary Sci. Rev., 26, 170-188, 2007.

Gasse, F., Arnold, M., Fontes, J. C., Fort, M., Gibert, E., Huc, A., Li, B. Y., Li, Y. F., Liu, Q., Melieres, M., Campo, E. V., Wang, F. B., and Zhang, Q. S.: A 13000-year climate record from western Tibet, Nature, 353, 742-745, 1991.

Giesecke, T. and Fontana, S. L.: Revisiting pollen accumulation rates from Swedish lake sediments, The Holocene, 18, 293-305, 2008.

Gregory, P. H.: The Microbiology of the Atmosphere, 2nd Edn., Leonard Hill, Aylesbury, 1973.

Goring, S., Lacourse, T., Pellatt, M. G., Walker, I. R., and Mathewes, R. W.: Are pollen-based climate models improved by combining surface samples from soil and lacustrine substrates?, Rev. Palaeobot. Palyno., 162, 203-212, 2010.

Grimm, E. C.: TGView Version 2.0.2. Illinois State Museum, Springfield, 2004.

Henderson, A. C. G., Holmes, J. A., and Leng, M. J.: Late Holocene isotope hydrology of Lake Qinghai, NE Tibetan Plateau: Effec- tive moisture variability and atmospheric circulation changes, Quaternary Sci. Rev., 29, 2215-2223, 2010.

Herzschuh, U.: Palaeo-moisture evolution in monsoonal Central Asia during the last 50,000 years, Quaternary Sci. Rev., 25, 163$178,2006$.

Herzschuh, U., Kramer, A., Mischke, S., and Zhang, C. J.: Quantitative climate and vegetation trends since the late glacial on the northeastern Tibetan Plateau deduced from Koucha lake pollen spectra, Quaternary Res., 71, 162-171, 2009.

Herzschuh, U., Birks, H. J. B., Mischke, S., Zhang, C., and Böhner, $\mathrm{J}$.: A modern pollen-climate calibration set based on lake sediments from the Tibetan Plateau and its application to a Late Quaternary pollen record from the Qilian Mountains, J. Biogeogr., 37, 752-766, 2010.

Herzschuh, U., Ni, J., Birks, H. J. B., and Böhner, J.: Driving forces of mid-Holocene vegetation shifts on the upper Tibetan Plateau, with emphasis on changes in atmospheric $\mathrm{CO}_{2}$ concentrationsm Quaternary Sci. Rev., 30, 1907-1917, 2011.

Hill, M. O. and Gauch, H. G.: Detrended correspondence analysis: An improved ordination technique, Vegetatio, 42, 41-58, 1980.

Hong, Y. T., Hong, B., Lin, Q. H., Shibata, Y., Hirota, M., Zhu, Y. X., Leng, X. T., Wang, Y., Wang, H., and Yi, L.: Inverse phase oscillations between the East Asian and Indian Ocean summer monsoons during the last 12000 years and paleo-El Nino, Earth Planet. Sc. Lett., 231, 337-346, 2005.

Huang, X. Z., Zhao, Y., Cheng, B., Chen, F. H., and Xu, J. R.: Modern pollen analysis of the surface sediments from the Bosten Lake, Xinjiang, China, J. Glaciol. Geocryol., 26, 602-609, 2004 (in Chinese with English abstract).

IJmker, J. M., Stauch, G., Pötsch, S., Diekmann, B., Wünnemann, B., and Lehmkuhl, F.: Dry periods on the NE Tibetan Plateau during the late Quaternary, Palaeogeogr. Palaeocl., 346-347, 108119, 2012.

Jacobson, G. L. J. and Bradshaw, R. H. W.: The selection of sites for paleovegetational studies, Quaternary Res., 16, 80-96, 1981.

Janssen, C. R.: Recent pollen spectra from the deciduous and coniferous-deciduous forests of Northeastern Minnesota: A study in pollen dispersal, Ecology, 47, 804-825, 1966.

Janssen, C. R.: Local and regional pollen deposition, in: Quaternary Plant Ecology, edited by: Birks, H. J. B. and West, R. G., Blackwell Oxford, 31-42, 1973.

Jiang, Q. F., Ji, J. F., Shen, J., Matsumoto, R., Tong, G. B., Qian, P., Ren, X. M., and Yan, D. Z.: Holocene vegetational and climatic variation in westerly-dominated areas of Central Asia inferred from the Sayram Lake in northern Xinjiang, China. Sci. China Earth Sci., 56, 339-353, 2013.

Juggins, S.: User guide C2 - a program for analysing and visualising palaeoenvironmental data, Department of Geography, University of Newcastle, UK, 2003.

Kramer, A., Herzschuh, U., Mischke, S., and Zhang, C. J.: Late glacial vegetation and climate oscillations on the southeastern Tibetan Plateau inferred from the Lake Naleng pollen profile, Quaternary Res., 73, 324-335, 2010a.

Kramer, A., Herzschuh, U., Mischke, S., and Zhang, C.: Holocene tree-line shifts and monsoon variability in the Hengduan Mountains (southeastern Tibetan Plateau) implications from palynological investigations, Palaeogeogr. Palaeocl., 286, 23-41, 2010 b. 
Kürschner, H., Herzschuh, U., and Wagner, D.: Phytosociological studies in the north-eastern Tibetan Plateau (NW China) - A first contribution to the subalpine scrub and alpine meadow vegetation, Botanische Jahrbücher der Systematik, 126, 273-315, 2005.

Laskar, J., Robutel, P., Joutel, F., Gastineau, M., Correia, A. C. M., and Levrard, B.: A long term numerical solution for the insolation quantities of the earth, Astron. Astrophys., 428, 261-285, 2004.

Liu, K. B., Yao, Z. J., and Thompson, L. G.: A pollen record of Holocene climatic changes from the Dunde ice cap, QinghaiTibetan Plateau, Geology, 26, 135-138, 1998.

Liu, X. Q., Dong, H. L., Yang, X. D., Herzschuh, U., Zheng, E. L., Stuut, J. W., and Wang, Y. B.: Late Holocene forcing of the Asian winter and summer monsoon as evidenced by proxy records from the northern Qinghai-Tibetan Plateau, Earth Planet. Sc. Lett., 280, 276-284, 2009.

Lu, H. Y., Wu, N. Q., Liu, K. B., Zhu, L. P., Yang, X. D., Yao, T. D., Wang, L., Li, Q., Liu, X. Q., Shen, C. M., Li, X. Q., Tong, G. B., and Jiang, H.: Modern pollen distributions in QinghaiTibetan Plateau and the development of transfer functions for reconstructing Holocene environmental changes, Quaternary Sci. Rev., 30, 947-966, 2011.

Lu, X. M., Herrmann, M., Mosbrugger, V., Yao, T. D., and Zhu, L. P.: Airborne pollen in the Nam Co Basin and its implication for palaeoenvironmental reconstruction, Rev. Palaeobot. Palyno., 163, 104-112, 2010.

Luly, J. G.: Modern pollen dynamics and surficial sedimentary processes at Lake Tyrrell, semi-arid northwestern Victoria, Australia, Rev. Palaeobot. Palyno., 97, 301-318, 1997.

Mischke, S., Herzschuh, U., Massmann, G., and Zhang, C. J.: An ostracod-conductivity transfer function for Tibetan lakes, J. Paleolimnol., 38, 509-524, 2007.

Mischke, S., Kramer, M., Zhang, C., Shang, H., Herzschuh, U., and Erzinger, J.: Reduced early Holocene moisture availability in the Bayan Har Mountains, northeastern Tibetan Plateau, inferred from a multi-proxy lake record, Palaeogeogr. Palaeocl., 267, 59-76, 2008.

Mischke, S., Zhang, C., Börner, A., and Herzschuh, U.: Lateglacial and Holocene variation in aeolian sediment flux over the northeastern Tibetan Plateau recorded by laminated sediments of a saline meromictic lake, J. Quaternary Sci., 25, 162-177, 2009.

Mischke, S., Bößneck, U., Diekmann, B., Herzschuh, U., Jin, H. J., Kramer, A., Wünnemann, B., and Zhang, C.J.: Quantitative relationship between water-depth and sub-fossil ostracod assemblages in Lake Donggi Cona, Qinghai Province, China, J. Paleolimn., 32, 589-608, 2010a.

Mischke, S., Aichner, B., Diekmann, B., Herzschuh, U., Plessen, B., Wünnemann, B., and Zhang, C. J.: Ostracods and stable isotopes of a late glacial and Holocene lake record from the NE Tibetan Plateau, Chem. Geol., 276, 95-103, 2010b.

Moore, P. D., Webb, J. A., and Collinson, M. E.: Pollen Analysis, 2nd edition. Blackwell Science, Oxford, 1991.

Morrill, C., Overpeck, J. T., and Cole, J. E.: A synthesis of abrupt changes in the Asian summer monsoon since the last deglaciation, The Holocene, 13, 465-467, 2003.

Morrill, C., Overpeck, J. T., Cole, J. E., Liu, K. B., Shen, C. M., and Tang, L. Y.: Holocene variations in the Asian monsoon in- ferred from the geochemistry of lake sediments in central Tibet, Quaternary Res., 65, 232-243, 2006.

Ni, J., Yu, G., Harrison, S. P., and Prentice, I. C.: Palaeovegetation in China during the late Quaternary: biome reconstructions based on a global scheme of plant functional types, Palaeogeogr. Palaeocl., 289, 44-61, 2010.

Oksanen, J., Kindt, R., Legendre, P., O’Hara, B., Simpson, G. L., Solymos, P., Stevens, M. H. H., and Wagner, H.: Vegan: community ecology package, R package version1, 15-1, 2008.

Opitz, S., Wünnemann, B., Aichner, B., Dietze, E., Hartmann, K., Herzschuh, U., Ijmker, J., Lehmkuhl, F., Li, S. J., Mischke, S., Plotzki, A., Stauch, G., and Diekmann, B.: Late Glacial and Holocene development of Lake Donggi Cona, north-eastern Tibetan Plateau, inferred from sedimentological analysis, Palaeogeogr. Palaeocl., 337-338, 159-176, 2012.

Overpeck, J., Anderson, D., Trumbore, S., and Prell, W.: The southwest Indian Monsoon over the last 18000 years, Clim. Dynam., 12, 213-225, 1996.

Paillard, D., Labeyrie, L., and Yiou, P.: Macintosh program performs time-series analysis, EOS Transactions AGU 77, 379, 1996.

Parsons, P. W. and Prentice, I. C.: Statistical approaches to R-values and the pollen-vegetation relationship, Rev. Paleobot. Palyno., 31, 127-152, 1981.

Pennington, W.: Seston and sediment formation in 5 lake district lake, J. Ecol., 61, 215-251, 1974.

Peres-Neto, P. and Jackson, D.: How well do multivariate data sets match? The advantages of a Procrustean superimposition approach over the Mantel test, Oecologia, 129, 169-178, 2001.

Prentice, I. C.: Pollen representation, source area, and basin size: toward a unified theory of pollen analysis, Quaternary Res., 23, 76-86, 1985.

Prentice, I. C.: Quantitative forest-composition sensing characteristics of pollen samples from Swedish lakes, Boreas, 16, 43-54, 1987.

R Development Core Team: R: A Language and Environment for Statistical Computing. R Foundation for Statistical Computing, Vienna, Austria, 2008.

Reimer, P. J., Baillie, M. G. L., Bard, E., Bayliss, A., Beck, J. W., Blackwell, P. G., Bronk Ramsey, C., Buck, C. E., Burr, G. S., Edwards, R. L., Friedrich, M., Grootes, P. M., Guilderson, T. P., Hajdas, I., Heaton, T. J., Hogg, A. G., Hughen, K. A., Kaiser, K. F., Kromer, B., McCormac, F. G., Manning, S. W., Reimer, R. W., Richards, D. A., Southon, J. R., Talamo, S., Turney, C. S. M., van der Plicht, J., and Weyhenmeyer, C. E.: IntCal09 and Marine09 radiocarbon age calibration curves, $0-50,000$ years cal BP, Radiocarbon, 51, 1111-1150, 2009.

Salonen, J. S., Seppae, H., Luoto, M., Bjune, A. E., and Birks, H. J. B.: A Northern European pollen-climate calibration set: analyzing the climate responses of a biological proxy using regression tree methods, Quaternary Sci. Rev., 45, 95-110, 2012.

Schlütz, F. and Lehmkuhl, F.: Holocene climatic change and the nomadic Anthropocene in Eastern Tibet: palynological and geomorphological results from the Nianbaoyeze Mountains, Quaternary Sci. Rev., 28, 1449-1471, 2009.

Schwartz, M. W.: Predicting tree frequencies from pollen frequency: An attempt to validate the R value method, New Phytol., 112, 129-143, 1989. 
Shan, F. S., Kong, Z. C., and Du, N. Q.: Palaeovegetation and environmental changes, in: Physical Environment of Hoh Xil Region, Qinghai, edited by: Li, B. Y., Science Press, Beijing, 197-206, 1996.

Shen, J., Liu, X. Q., Wang, S. M., and Matsumoto, R.: Palaeoclimatic changes in the Qinghai Lake area during the last 18,000 years, Quaternary Int., 136, 131-140, 2005.

Shen, C. M., Liu, K. B., Tang, L. Y., and Overpeck, J. T.: Quantitative relationships between modern pollen rain and climate in the Tibetan Plateau, Rev. Palaeobot. Palyno., 140, 61-77, 2006.

Soria-Auza, R. W., Kessler, M., Bach, K., Barajas-Barbosa, P. M., Lehnert, M., Herzog, S. K., and Böhner, J.: Impact of the quality of climate models for modelling species occurrences in countries with poor climatic documentation: a case study from Bolivia, Ecol. Model., 221, 1221-1229, 2010.

Stauch, G., IJmker, J., Pötsch, S., Zhao, Y., Hilgers, A., Diekmann, B., Dieter, E., Hartmann, K., Opity, S., Wünnemann, B., and Lehmkuhl, F.: Aeolian Sediments on the north-eastern Tibetan Plateau, Quaternary Sci. Rev., 4, 71-84, 2012.

Sugita, S.: A model of pollen source area for an entire lake surface, Quaternary Res., 39, 239-244, 1993.

Sugita, S.: Pollen representation of vegetation in Quaternary sediments: Theory and method in patchy vegetation, J. Ecol., 82, 881-897, 1994.

Sun, X. J. and Wu, Y. S.: Distribution and quantity of sporopollen and algae in surface sediments of the Dianchi Lake, Yunnan Province, Mar. Geol. Quaternary Geol., 17, 81-92, 1987 (in Chinese with English abstract).

Tang, L. Y., Shen, C. M., Liu, K. B., Yu, S. Y., and Li, C. H.: Climatic changes in southeast Tibet since LGM: Evidences from Pollen records, Sci. China Ser. D: Earth Sciences, 34, 436-442, 2004 (in Chinese).

Tauber, H.: Differential pollen dispersion and the interpretation of pollen diagrams, Danmarks Geologiske Undersoegelse, Raekke 2, 1-69, 1965.

Tauber, H.: Investigations of aerial pollen transport in a forested area, Dansk Botanisk Arkiv, 32, 1-121, 1977.

ter Braak, C. J. F. and Šmilauer, P.: CANOCO for Windows 4.5, Biometrics, the Netherlands, 2002.

Thompson, L. G., Yao, T. D., Davis, M. E., Henderson, K. A., Mosley-Thompson, E., Lin, P. N., Beer, J., Synal, H. A., ColeDai, J., and Bolzan, J. F.: Tropical climate instability: the last glacial cycle from a Qinghai-Tibetan Ice Core, Science, 276, 1821-1825, 1997.

Van Campo, E., Cour, P., and Hang, S. X.: Holocene environmental changes in Bangong Co basin (Western Tibet). Part 2: The pollen record, Palaeogeogr. Palaeocl., 120, 49-63, 1996.

Vandenberghe, J., Renssen, H., Huissteden, K., Nugteren, G., Konert, M., Lu, H. Y., Dodonov, A., and Buylaert, J.-P.: Penetration of Atlantic westerly winds into Central and East Asia, Quaternary Sci. Rev., 25, 2380-2389, 2006.

Wang, F. X., Chen, N., Zhang, Y., and Yang, H.: Pollen flora of China, Science Press, Beijing, 1997 (in Chinese).

Wang, S. M. and Dou, H. S. (chief Eds.): Lakes in China, Science Press, Beijing, 1998.

Wang, W. Y., Wang, Q. J., Li, S. X., and Wang, G.: Distribution and species diversity of plant communities along transect on the northeastern Tibetan Plateau, Biodivers. Conserv., 15, 18111828, 2006.
Wang, Y. J., Cheng, H., Edwards, R. L., He, Y. Q., Kong, X. G., An, Z. S., Wu, J. Y., Kelly, M. J., Dykoski, C. A., and Li, X. D.: The Holocene Asian Monsoon links to Solar changes and North Atlantic Climate, Science, 308, 854-857, 2005.

Wang, Y. B., Liu, X. Q., and Herzschuh, U.: Asynchronous evolution of the Indian and East Asian Summer Monsoon indicated by Holocene moisture patterns in monsoonal central Asia, EarthSci. Rev., 103, 135-153, 2010.

Wang, Y. B., Liu, X. Q., Mischke, S., and Herzschuh, U.: Environmental constraints on lake sediment mineral compositions from the Tibetan Plateau and implications for palaeoenvironment reconstruction, J. Paleolimn., 47, 71-85, 2012.

Wischnewski, J., Mischke, S., Wang, Y. B., Herzschuh, U.: Reconstructing climate variability on the northeastern Tibetan Plateau since the last Late glacial - a multi-proxy, dual-site approach comparing terrestrial and aquatic signals, Quaternary Sci. Rev., 30, 82-97, 2011.

Xu, Q. H., Li, Y. C., Yang, X. L., Xiao, J. L., Liang, W. D., and Peng, Y. J.: Source and distribution of pollen in the surface sediment of Daihai Lake, inner Mongolia, Quaternary Int., 136, 33-45, 2005.

Xu, Q. H., Xiao, J. L., Li, Y. C., Tian, F., and Nakagawa, T.: Pollenbased quantitative reconstruction of Holocene climate changes in the Daihai Lake area, inner Mongolia, China, J. Climate, 23, 2856-2868, 2010a.

Xu, Q. H., Li, Y. C., Bunting, M. J., Tian, F., and Liu, J. S.: The effects of training set selection on the relationship between pollen assemblages and climate parameters: Implications for reconstructing past climate, Palaeogeogr. Palaeocl., 289, 123-133, 2010b.

Yan, G., Wang, F. B., Shi, G. R., and Li, S. F.: Palynological and stable isotopic study of palaeo-environmental changes on the northeastern Tibetan plateau in the last 30,000 years, Palaeogeogr. Palaeocl., 153, 147-159, 1999.

Yu, G., Prentice, I. C., Harrison, S. P., and Sun, X. J.: Pollen-based biome reconstructions for China at 0 and 6000 years, J. Biogeogr., 25, 1055-1069, 1998.

Yu, G., Tang, L. Y., Yang, X. D., Ke, X. K., and Harrison, S. P.: Modern pollen samples from alpine vegetation on the Tibetan Plateau, Global Ecol. Biogeogr., 10, 503-519, 2001.

Zhang, C. J. and Mischke, S.: A Late glacial and Holocene lake record from the Nianbaoyeze Mountains and inferences of lake, glacier and climate evolution on the eastern Tibetan Plateau, Quaternary Sci. Rev., 28, 1970-1983, 2009.

Zhao, Y., Yu, Z. C., Chen, F. H., Zhang, J. W., and Yang, B.: Vegetation response to Holocene climate change in monsoon-influenced region of China, Earth-Sci. Rev., 97, 242-256, 2009a.

Zhao, Y., Xu, Q. H., Huang, X. Z., Guo, X. L., and Tao, S. C.: Differences of modern pollen assemblages from lake sediments and surface soils in arid and semi-arid China and their significance for pollen-based quantitative climate reconstruction, Rev. Palaeobot. Palyno., 156, 519-524, 2009b.

Zhu, Y., Chen, F. H., and Madsen, D.: The environmental signal of an early Holocene pollen record from the Shiyang River basin lake sediments, NW China, Chinese Sci. Bull., 47, 267-273, 2002.

Zuur, A. F., Leno, E. N., and Smith, G. M.: Analysing Ecological Data, Springer, New York, 2009. 